
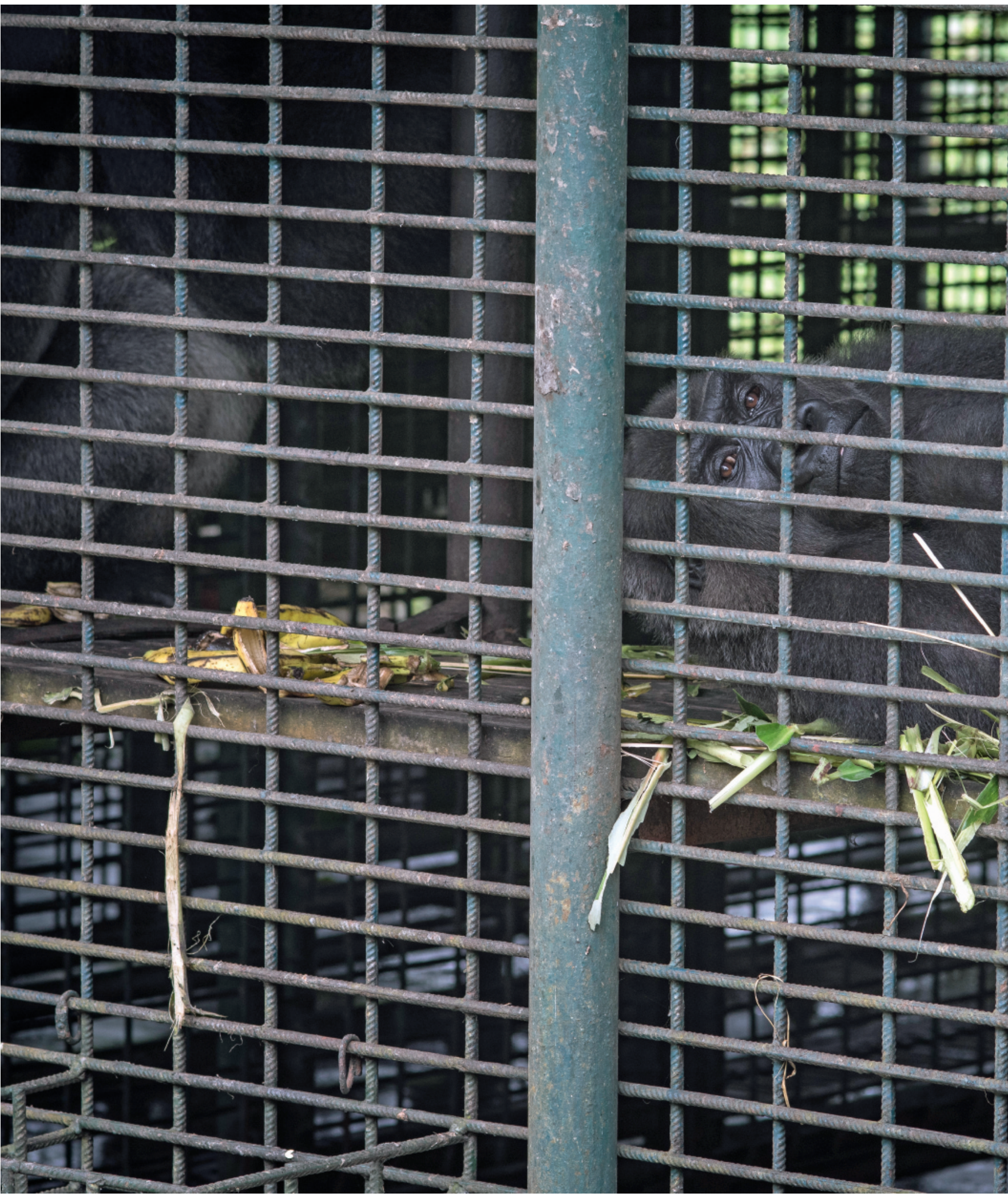


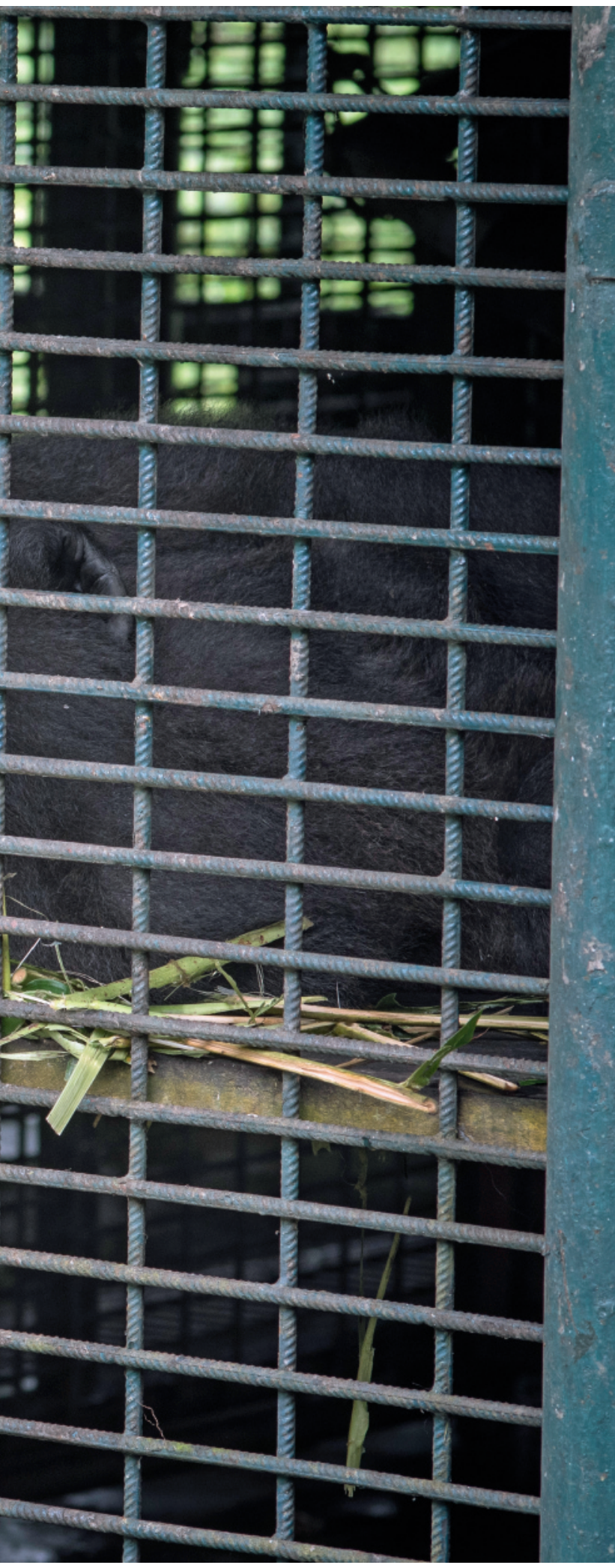

CHAPTER 6

\section{Protecting Apes: The Legal and Regulatory Environment}

\section{Introduction}

The preceding chapters explore a variety of issues related to the illegal wildlife trade, including its social and economic drivers, its effects on apes and their habitat, and the ways in which it may be addressed, such as through law enforcement efforts (see Chapter 5). This chapter focuses on the legal and regulatory frameworks within which ape hunters, traders and consumers operate, and considers how they may be applied to disrupt and interdict the use of and trade in live apes, their parts and their meat around the world.

The first part of the chapter looks at national laws that govern the protection of species. These laws stipulate geographical areas of protection; the conditions under 


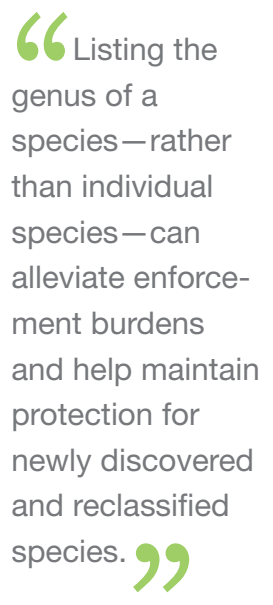

66 Listing the

genus of a

species - rather

than individual

species-can

alleviate enforce-

ment burdens

and help maintain

protection for

newly discovered

and reclassified

species. 9 which individuals may be removed from the wild, bred, held in captivity and transported; permission and reporting requirements; and fines and penalties that apply when a law is broken. The chapter also covers domestic legislation implementing a country's obligations under the Convention on International Trade in Endangered Species of Wild Fauna and Flora (CITES), the main international agreement in this field (CITES, n.d.-k).

This section draws on a detailed analysis of relevant legislation in 17 ape range states (Rodriguez et al., 2019). The Arcus Foundation commissioned the legal intelligence firm Legal Atlas to conduct the initial study in 2018 and to produce this chapter as a synthesis of the findings. Full study results are available on the Legal Atlas website, which also presents previous research findings relating to other countries' laws (Legal Atlas, n.d.). ${ }^{1}$

The selected countries all have a field presence of Arcus-supported programs that assisted the authors by collecting information on national laws. Since the study focuses on just 17 (55\%) of the 31 total range states23 of which are home to great apes ${ }^{2}$ and 11 to gibbons, ${ }^{3}$ while 2 harbor both groups-it does not shed light on the particularities of the illegal ape trade in the 14 excluded range countries. As the aim of the study was to understand and compare the different legal architectures in place to protect apes, however, the sample does succeed in providing a representative cross-section, capturing the most common legal principles, trends and elements to consider. On average, the authors reviewed about 20 laws for each country, assessing which parts of the trade chain they regulate and how, what kinds of penalties they apply for violations and which national institutions are relevant. This kind of analysis is crucial to understanding how a national legal framework can provide an effective deterrent to the illegal removal of and trade in apes (Rodriguez et al., 2019).
The second part of the chapter examines the legal frameworks that regulate the trade in apes outside their country of origin. The main legal framework of relevance is CITES, which uses a system of export and import permits to regulate the international trade in endangered species of wildlife. In principle, CITES provides a good system, and it has had many successes, but the implementation of its obligations at the national level leaves much to be desired, whether because of a lack of capacity, the absence of political will, corruption, or a combination of the three.

While the CITES system can place pressure on non-complying parties to fulfill their obligations, CITES itself is not an enforcement agency. This section therefore reviews a range of other international organizations that do have the power-and, sometimes, the resources-to pursue enforcement action across borders, including INTERPOL and the World Customs Organization (WCO). The section also considers organizations such as the Great Apes Survival Partnership (GRASP) and the UN Office on Drugs and Crime (UNODC), which have valuable roles to play in research, awareness raising and capacity building; in addition, it reviews a number of interventions that have been coordinated across countries and between agencies.

The trade in apes is a matter of substantial concern, yet it is not the only threat to their survival; loss and fragmentation of habitats under the pressures of economic development are probably more significant. Accordingly, this section also provides a brief assessment of the main international agreements of relevance to the conservation of apes and their habitats.

The key findings include:

- Given that the illegal wildlife trade is transnational for the most part, enforcement opportunities would increase if all countries were to include all great ape 
and gibbon species, both native and non-native, in their domestic lists of protected wildlife.

- Legislation that prohibits the removal of great apes and gibbons from the wild stands to be more effective if it explicitly criminalizes all related actionsfrom transport, storage and processing to exhibition, experimentation, advertising, domestic and foreign trade, use and possession.

- Countries are effective at criminalizing domestic and foreign trade of illegally taken species, but they can do more to close regulatory gaps and to increase enforcement opportunities along the entire value chain, particularly with respect to acts associated with transport, processing, storage, advertising, welfare, possession and exhibition of wildlife.

- Including non-native species in domestic lists of protected species can expand both local and international enforcement opportunities.

- Listing the genus of a species-rather than individual species-can alleviate enforcement burdens and help maintain protection for newly discovered and reclassified species.

- To adapt punishments to the type of offender and offense, jurisdictions can usefully establish differential forms of liability - that is, higher penalties for the involvement of criminal enterprises and government officials, and tougher penalties in the case of aggravating circumstances, repeat offenses and intentionality, as well as for greater volumes and values.

- International criminal networks fuel transnational wildlife crime by corrupting enforcement and justice structures across countries. Legal systems that focus on poachers can thus become more effec- tive by expanding their scope to target these networks as well as the legal entities and governmental officials involved.

- By fully utilizing available economic and legal tools, countries could establish administrative and criminal penalties that more effectively deter and prevent wildlife crime, and that compensate for damage caused.

- None of the countries under review has established a wildlife crime task force to coordinate prevention efforts, intelligence gathering, investigations and prosecution of wildlife crimes, even though it is best practice to do so. Moreover, these states lack the legal mechanisms for effective coordination of wildlife law enforcement.

- CITES provides a largely adequate international legal framework, but it could do more to curb abuse by safaris, amusement parks and so-called zoos by rejecting all applications for trade in potentially wild-caught apes, save in exceptional circumstances.

- In the context of combating the illegal ape trade, CITES suffers less from design weaknesses than it does from the lack of capacity, resources and political will in many of its members, particularly ape range states and countries that see imports of apes for commercial purposes.

- INTERPOL and the WCO are in a position to coordinate effective enforcement action against the illegal trade in apes, but they struggle due to a shortage of resources and many competing priorities.

- Increased dedicated support from donors is needed for the implementation of CITES and cross-border enforcement operations, as well as for awareness raising activities, research and campaigning aimed at reducing the demand for illegally traded great apes and gibbons.
Legal systems that focus on poachers can become more effective by expanding their scope to target the criminal networks, legal entities and governmental officials involved. 
Photo: Although the regulation of international trade in wildlife is of paramount concern, the laws that govern domestic transactions are arguably the most important. Orangutan rescue IAR Indonesia. (C) IAR Indonesia/ Heribertus Suciad

\section{The National Legal Environment: Trend Analysis $^{4}$}

\section{Law, Policy and Enforcement as Mutually Reinforcing}

Proponents of enhancing wildlife laws are sometimes criticized for overemphasizing the role of legislation and underestimating the need for more effective policies and enforcement (Chen et al., 2011). Those who argue that wildlife crime should become a priority on the policy agenda call on policymakers to recognize illegal wildlife trade not only as a conservation matter, but also as a core governance concern (Robertson, 2017). Those who focus on enforcement point to critical limitations in implementing laws that are already on the books, and in achieving even basic conditions for the rule of law. They demand urgent action to address a host of enforcement challenges, such as corruption, insufficient capacity of field personnel, and a lack of technological and financial resources (Ariffin, 2018). Some go so far as to defend the idea that unenforced laws are worse than no laws at all (Chen, 2013).

This chapter seeks to demonstrate that the need for more effective policies and enforcement does not invalidate the call for better legislation. It argues that a comprehensive, integrated suite of legal, policy and enforcement tools is required to combat the illegal wildlife trade. In this context, it underscores the foundational role of the law. Unless policy is translated into law, it lacks enforceability and may not survive changes in political agendas. Law also defines the playing field for enforcement. This chapter is designed to promote a better understanding of how current legislation governs wildlife management and enforcementand of how the development of more effective laws, not simply more laws, can bolster the fight against the illegal wildlife trade.

\section{Applicable Law along the Supply Chain: From the Wild to Market to Consumer}

Although the regulation of international trade in wildlife is a major concern, there are several reasons why the laws that govern domestic activities and transactions are arguably the most important. The extent to which a species is protected is almost exclusively determined by national laws that govern domestic activities and transactions. These laws define the geographical area of protection; the conditions under which wildlife may be removed from the wild, bred, held in captivity and transported; permission and reporting requirements; and fines and penalties that apply when a law is broken. Even international trade in wildlifewhich is governed by CITES and other general trade agreements-must be implemented through domestic legislation. The relative importance of national legislation in this area reflects geopolitical realities: While the total length of terrestrial and maritime international borders is in the order of hundreds of thousands of kilometers, the total land area of all countries around the globe is almost 150 million $\mathrm{km}^{2}$ ( 15 billion ha) (Worldometer, n.d.). Passing through customs and crossing a border accounts for far less time than conducting the preceding and ensuing activities within national bordersbe it in the wild, on the road, through physical mail systems, or in markets, restaurants or shops. These activities are exclusively defined by national laws and mandates, few of which are directly associated with wildlife or wildlife crime. If these laws lack explicit provisions governing wildlife trade, opportunities to control detrimental trade are significantly reduced.

In reviewing how national legislation governs the trade in wildlife, it is useful to bear two points in mind. First, countries typically do not legislate solely in the interest 


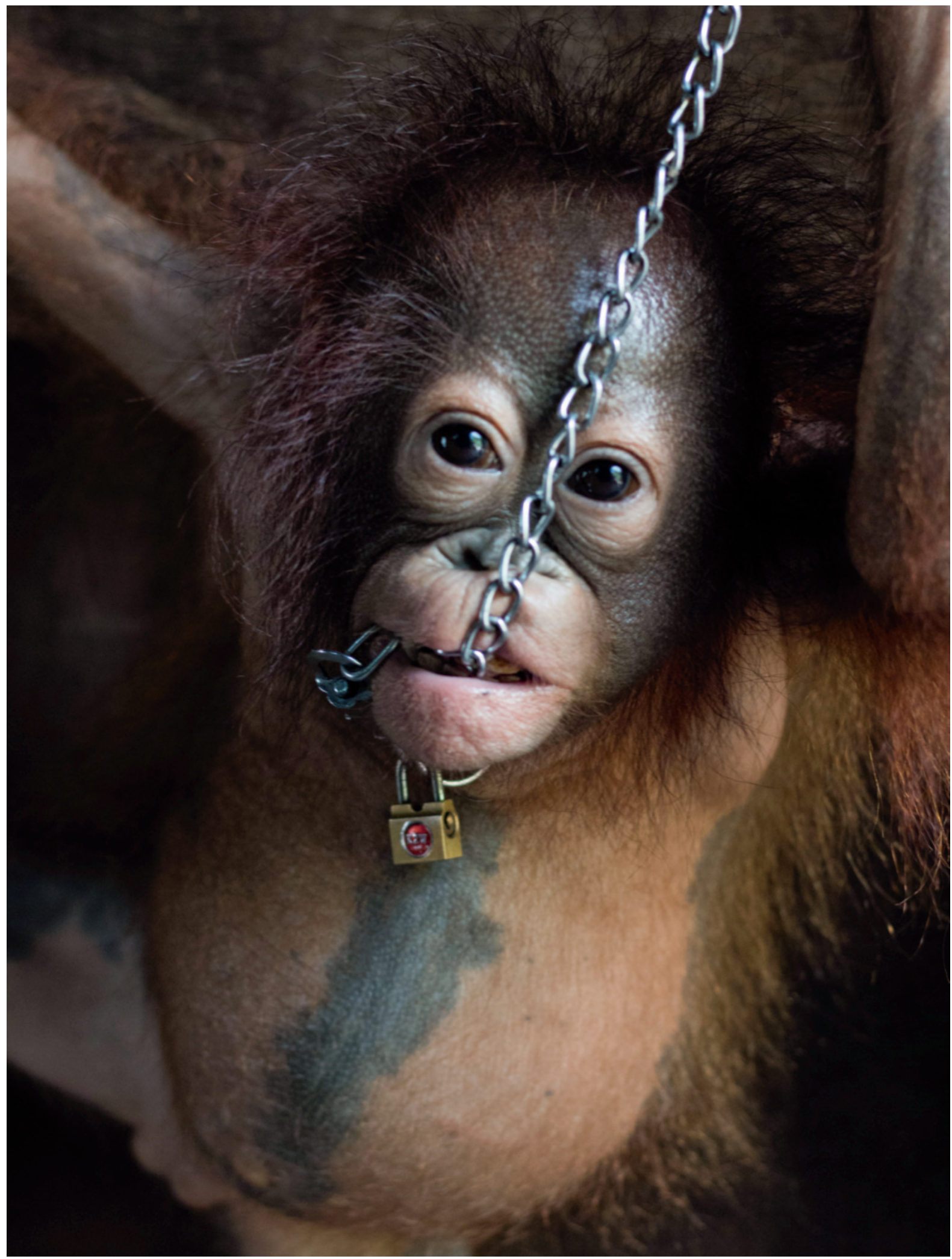


of a single species or group of species. There are exceptions to this general practice, but only a few. Among them are China's ban on the trade in tiger bones and rhino horn, which was approved in 1993, and the United Kingdom's 2018 ban on the ivory trade (State Council, 1993; The Stationery Office, 2018). On the whole, however, relevant laws are directed at wildlife in general. In the 17 countries under review, no legislation specifically addresses great apes or gibbons.

The second point to note is that, as illegal wildlife trade comprises a complex array of individual criminal acts, offenses may be covered by a variety of domestic laws. From the instant a hunter enters a protected area or poaches a chimpanzee anywhere to the time the captive animal is purchased or kept as a pet, any number of individuals may undertake any number of activities and transactions, all of which may be regulated by a variety of laws, sometimes simultaneously. A state's endangered species act, for example, may govern the hunting and capture of protected species, even if protected area, forestry and hunting legislation does so as well. The use of specific take methods and firearms may be proscribed by legislation on protected areas, hunting, firearms and forestry. Transport, traditional medicine, phytosanitary and animal welfare laws, among others, may govern the transport, processing, storage and use of wildlife. Laws on quarantine, customs, tax, border control, and crime may regulate transport, smuggling and associated financial transactions. In jurisdictions where wildlife trafficking is recognized as a predicate offense, anti-money-laundering statutes may apply. The falsification of documents, use of corrupt practices and involvement of criminal organizations may be covered by yet more laws.

Based on long-term research of legislation in more than 60 countries, Legal Atlas has identified 43 types of domestic law that could apply in wildlife cases, depending on the country. ${ }^{5}$ Whatever the number of laws and particular approach, robust national legal frameworks govern all elements of the wildlife supply chain-from the wild to the final consumer. They allow for the tracking of animals, body parts and related products, such as ointments, jewelry and decorative items, from their habitat to hunters and traders, through transportation systems, to processors and the final market. In this way, they offer the greatest enforcement opportunities.

\section{Legal Protections for Great Apes and Gibbons}

\section{Listing Status as a Cornerstone}

At the domestic level, the legal protection for apes can take several forms. One of the more typical forms is a legally defined domestic list of endangered species. Species listing is the legal mechanism by which species are added to a national list and provided stricter protection. Since it is typically tied to numerous other legal instruments, species listing is a cornerstone of domestic wildlife protection and can have a pervasive impact on the control of wildlife crime.

In most jurisdictions, species status in a list is tied to legal instruments such as bans, permits, business licenses and penalties, which, in turn, are found in multiple pieces of legislation that regulate distinct parts of the trade chain, including protected areas, national markets, restaurants, airports, roads and the virtual space. Such instruments can be "triggered" by species listing; for example, the listing of an endangered species triggers the application of a hunting prohibition, as well as increased fines for those who violate the prohibition. By triggering such other instruments, species listing can expand the degree of protection afforded to particular species, while also determining punishments for a broad range of offense types. All 17 countries under review use a 
listing format and provide greater protection for the species included in their national list.

Approaches to listing vary across countries, however, and the lack of a standard creates inconsistencies in the process by which species are protected and the levels of protection they are given. The Red List of the International Union for Conservation of Nature (IUCN) - which is "based on an objective system for assessing the risk of extinction of a species based on past, present, and projected threats"-is the closest to a global standard for the scientific categorization of species (IUCN, 2012). It applies different categories based on criteria linked to population size, structure and trends, as well as geographic range (see Box $\mathrm{AO}_{1}$ and Annex I).

\section{TABLE 6.1}

\section{Red List Categories and Inconsistent Classification Systems in Three Jurisdictions}

\begin{tabular}{|l|l|l|}
\hline \multicolumn{2}{|l|}{ Scientific Categorization of Species } \\
\hline IUCN Red List Categories \\
\hline EX & Extinct \\
\hline EW & Extinct in the wild & \\
\hline CE & Critically endangered & \\
\hline EN & Endangered & \multirow{2}{*}{ Threatened } \\
\hline VU & Vulnerable & \\
\hline NT & Near threatened & \\
\hline LC & Least concern \\
\hline
\end{tabular}

\section{Legal Classification of Species}

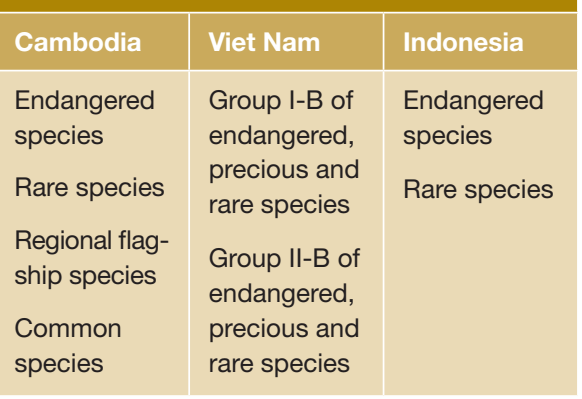

Sources: IUCN (2012); Rodriguez et al. (2019)
In contrast, legal categories for protected species vary widely across jurisdictions, which use terms such as "endangered species," "rare species" or "class I species"-classifications that are not necessarily consistent with the IUCN Red List categories or with each other. Table 6.1 presents terminology used in three selected countries and compares them to the Red List categories, indicating how the legal systems are not consistent with each other or with the scientific system. The "rare species" category, for example, may be based on population estimates, but it does not necessarily reflect a decreasing trend in the local population. Countries that use this category may list species that are technically rare in their jurisdiction, but not necessarily threatened by trade or habitat loss.

Countries also use different legal instruments to list species. Seven of the 17 reviewed countries list species in laws issued by a national legislative body, while the other ten use more flexible ministerial regulations (see Table 6.2). Laws issued by a national legislative body create the foundation for all subsidiary regulations and require substantial periods-sometimes many yearsto be drafted, negotiated and approved. Regulations, on the other hand, are intended to implement existing laws and are generally not subject to the same level of political negotiation. Considering only time frames, species listing based on regulations thus represents a more flexible tool that can react to population studies or new CITES resolutions. The orientation of national legislative bodies also means that the listing process may not be an exclusively technical procedure, but rather one that can be compromised by political agendas and priorities.

Amending the national list also tends to be more time-consuming than passing a ministerial regulation and can therefore lag behind identified needs (EPA, n.d.). Only seven of the countries reviewed in 2018 , for example, had amended their species list within 
TABLE 6.2

Domestic Laws and Regulations that Protect Great Apes and Gibbons in 17 Ape Range States, 2018

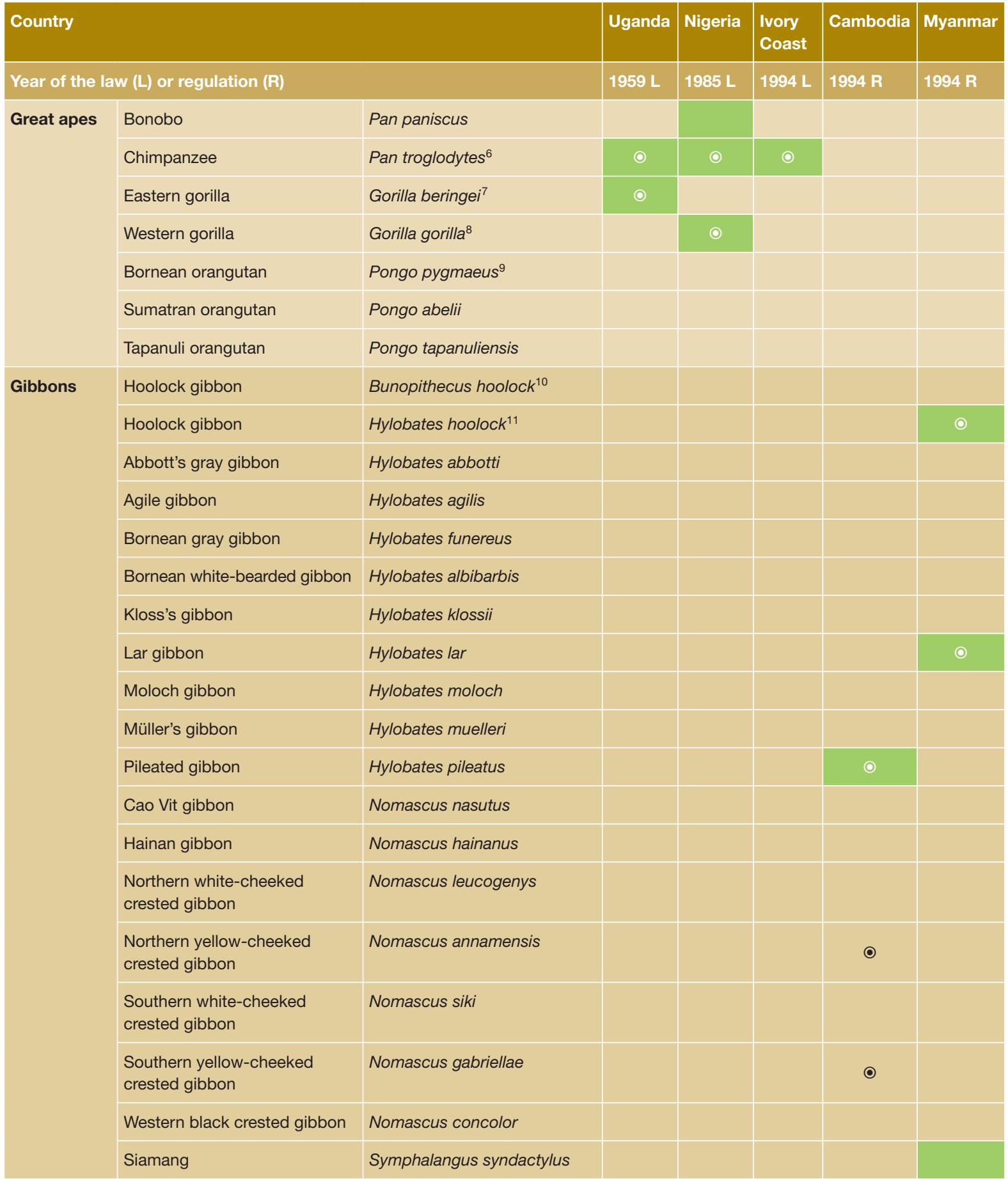

Notes: All great apes and gibbons, except for the Tapanuli orangutan (Pongo tapanuliensis), are listed in CITES Appendix I, which comprises the most endangered of CITESlisted species. The Appendix does not list the Tapanuli orangutan as it pre-dates the identification of this species.

Sources: CITES (2017a); IUCN (2018); Rodriguez et al. (2019); UNEP-WCMC and CITES Secretariat (n.d.) 
Key: $\bigcirc$ Native species Domestic legal protection

\begin{tabular}{|c|c|c|c|c|c|c|c|c|c|c|c|}
\hline Lao PDR & China & Cameroon & DRC & Viet Nam & Rwanda & $\begin{array}{l}\text { Malaysia } \\
\text { (Peninsular) }\end{array}$ & $\begin{array}{l}\text { Republic } \\
\text { of Congo }\end{array}$ & Tanzania & Liberia & Indonesia & Guinea \\
\hline \multirow[t]{15}{*}{2003 R } & 2003 R & $2006 R$ & 2006 R & 2006 R & $2008 \mathrm{R}$ & 2010 L & $2011 R$ & 2013 L & 2016 L & 2018 R & 2018 L \\
\hline & & & O & & & & 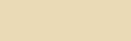 & - & 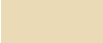 & 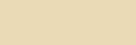 & \\
\hline & & 0 & 0 & & 0 & & O & 0 & ( ) & & 0 \\
\hline & & & 0 & & O & & & & . & & \\
\hline & & 0 & & & & & 0 & & & & \\
\hline & & & & & & 0 & & & & 0 & \\
\hline & & & & & & & & & & 0 & \\
\hline & & & & & & & & & & 0 & \\
\hline & & & & & & & & & 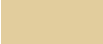 & & \\
\hline & & & & & & & & & & & \\
\hline & & & & & & 0 & & & & 0 & \\
\hline & & & & & & 0 & & & & 0 & \\
\hline & & & & & & 0 & & & & O & \\
\hline & & & & & & & & & & 0 & \\
\hline & & & & & & & & & & O & \\
\hline \multirow[t]{3}{*}{ O } & ( & & & & & ( & & & & O & \\
\hline & & & & & & & & & & O & \\
\hline & & & & & & & & & & 0 & \\
\hline \multicolumn{12}{|l|}{0} \\
\hline & 0 & & & 0 & & & & & & & \\
\hline & 0 & & & & & & & & & & \\
\hline 0 & 0 & & & 0 & & & & & & & \\
\hline ○ & & & & ○ & & & & & & & \\
\hline ○ & & & & ○ & & & & & & & \\
\hline ○) & & & & O & & & & & & & \\
\hline \multirow[t]{2}{*}{ O } & ( ) & & & 0 & & & & & & & \\
\hline & & & & & & 0 & & & & 0 & \\
\hline
\end{tabular}


66 Listing non-

native species

in addition to

native species

increases the

opportunities for

law enforcement to

prevent and stop

illegally harvested

species from being

trafficked. the previous decade. Nigeria and Uganda represent extreme cases, with national lists that have not been amended in 34 years and 60 years, respectively. Unsurprisingly, such static national lists are highly unlikely to include all the relevant species protected under CITES, whose appendices are continually updated to reflect ongoing developments (CITES, n.d.-i). ${ }^{12}$

\section{Approaches for Domestic Protection}

Domestic protection of native great apes and gibbons is common, but not universal. In its review of the 17 ape range states, Legal Atlas documented the use of four approaches to the listing of great apes and gibbons. These can be ranked as either more or less inclusive and have an impact on enforcement opportunities. The most inclusive approach automatically places all species listed in CITES Appendix I on the national list, regardless of whether they are native to the country. Guinea, Malaysia and Tanzania all use this method, which guarantees that national listing shall never be out of date with respect to CITES listing. The second approach lists only some non-native great apes and gibbons. This system is used in China, which lists 15 gibbon species although only four are native to the country; the Democratic Republic of Congo (DRC), which includes one non-native gorilla; ${ }^{13}$ Myanmar, whose list features one non-native gibbon; and Nigeria, which lists the non-native bonobo. The third approach protects exclusively native species and is employed in Indonesia, Ivory Coast, Liberia, Rwanda and Uganda. In the fourth and least inclusive method, countries list some, but not all, of their native great apes and gibbon species. This is the case for Cambodia, Lao People's Democratic Republic (PDR) and Viet Nam. The good news is that domestic protection for native great apes and gibbons is largely granted across the study set, with the exception of the last three countries mentioned. For these, the omission of between two and three native species from their protected species lists represents a legal gap that needs to be addressed.

Listing non-native species in addition to native species increases the opportunities for law enforcement to prevent and stop illegally harvested species from being trafficked. It does so in several ways. First, it can ease enforcement burdens by eliminating the need to specifically identify species. This impact is particularly important for enforcement officials, who may have little or no training in this regard. If, for instance, road control officers in China intercept a gibbon who originated in Lao PDR, China's inclusive listing would allow the authorities to identify the genus rather than the individual species, which could require expertise or techniques that may not be readily available.

Second, listing a non-native genus offers all species within that genus protection, regardless of where they hail from; it also eliminates the potential for gaps in protection that may be inadvertently created by changes in taxonomy or new discoveries. A case in point is the recently discovered northern yellow-cheeked crested gibbon (Nomascus annamensis). Four of the countries under review-China, Guinea, Myanmar and Tanzania - protect the Nomascus gibbon genus as a whole and thus automatically provided legal protection when the new species was identified. In contrast, new species may fall into a legislative gap in countries that only protect specifically listed native or non-native species, such as Cambodia, Lao PDR and Viet Nam.

A third enforcement impact of species listing is the opportunity to use anti-moneylaundering statutes against criminal organizations that profit from smuggled wildlife that is native to other jurisdictions. While such laws can only be used in prosecution 
if a predicate crime has been committed, they can serve to impose additional or higher penalties on individuals in the financial chain. If the relevant non-native species is not listed or protected in the country, there may be no case to pursue (Wingard and Pascual, 2019).

\section{Regulating the Ape Trade along the Supply Chain}

All countries under review have passed legislation that criminalizes activities at the beginning and end of the supply chain: the capture of an animal (also known as "take" in legal contexts), the final purchase and any related import or export transactions. Offenses that relate to the illegal removal of an animal from the wild are well developed in all these states; they include violations of hunting bans, detailed lists of prohibited methods, and closed areas and seasons. All 17 surveyed countries apply a complete national ban on the hunting and removal of listed great apes and gibbons (see Table 6.3); in Cambodia, Lao PDR and Viet Nam, however, a few native gibbon species remain unlisted and therefore unprotected (see Table 6.2).

As noted, all states have enacted offenses related to domestic trade as well as the import and export of endangered wildlife, to varying degrees of detail. The sale and purchase of wildlife, for example, are penalized as two separate offenses in 12 countries. The remaining jurisdictions use the generic term "trade" without defining it further. Import and export are controlled by CITES implementing laws that are present in all of the reviewed jurisdictions, as well as customs and quarantine regulations that generally prohibit the smuggling of goods, including wildlife.

When it comes to regulating other activities along the supply chain-particularly following take and trade crimes-most of the countries under review exhibit significant legal gaps. These gaps relate largely to the transport, processing and storage of wildlife, as well as to advertising, welfare, possession and exhibition. Countries that regulate one activity do not necessarily regulate the others. Rwanda, for example, has enacted offenses related to transport, but not to storage or possession. Processing (including taxidermy) is only criminalized in Cambodia, China, Malaysia and Viet Nam. To the extent that the wild meat trade involves processing, the absence of this criminal offense in areas where this type of trade is prevalent is cause for concern. Meanwhile, at a time when unregulated Internet trade is booming, only China and Malaysia have criminalized advertising of wildlife. In addition to the many difficulties that the physical trade in species presents, cyber-enabled trade adds jurisdictional challenges that most legal systems in the world have yet to address (Wingard and Pascual, 2018).

Legal systems that do not target each part of the supply chain ultimately create weaknesses that can be exploited by criminals. They also forgo opportunities to hold individuals involved in the illegal wildlife trade liable for criminal acts. For great apes and gibbons, along with other endangered species, such patchy legal regimes translate into greater vulnerability and a higher risk of being trafficked-or losing community members to the trade. These findings are consistent with those of a recent study of the great ape supply chain:

\footnotetext{
For the illegal trade in great apes as well as the illegal wildlife trade as a whole, attention has often been directed to the ends of the supply chain-the poaching incident and the final consumer purchase-both in terms of intelligence as well as intervention. What remains relatively murky is what goes on in between, that is the "business" of the trade and more importantly the financial side of the business (GFI, 2018).
}

Legal systems that do not target each part of the supply chain ultimately create weaknesses that can be exploited by criminals. 


\section{TABLE 6.3}

\section{Criminalization of Activities along the Ape Supply Chain in 17 Ape Range States, 2018}

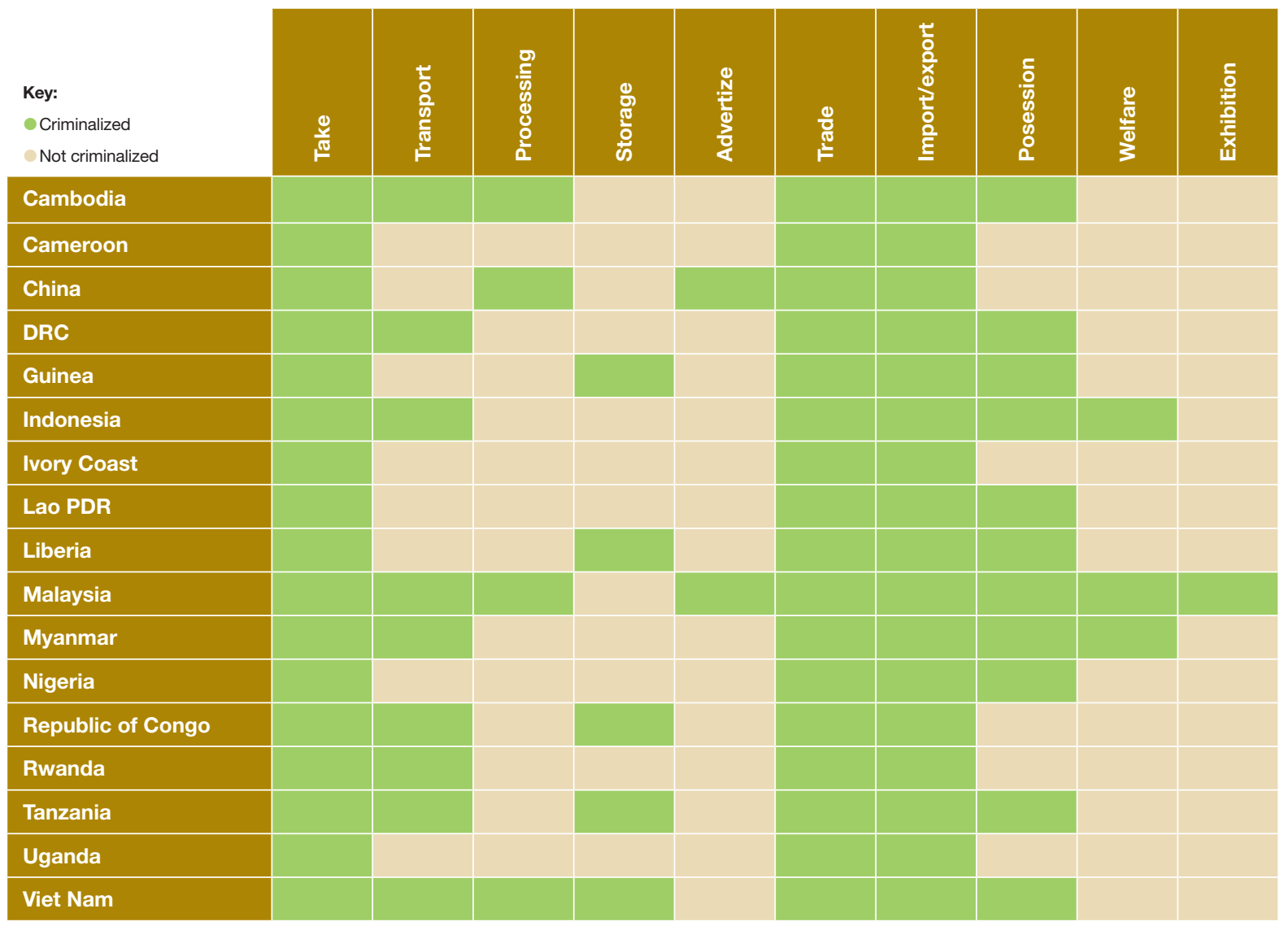

\section{Focus on Three Offense Types}

This review entails an in-depth analysis of three particular types of offense-hunting, domestic sales and advertising of apesacross the 17 selected jurisdictions. The decision to limit the analysis to these offenses was made for a number of reasons. For one, it is beyond the scope of this study to analyze all offense types, especially since it is not uncommon for jurisdictions to list upwards of 100 wildlife-related crimes, including all variants. Limiting the number to three allows for some depth of analysis in this context. Offenses relating to hunting and domestic sales were selected because they are criminalized in all jurisdictions under review and regulate key points along the supply chain: the capture and the sale of apes. ${ }^{14}$

Offenses pertaining to advertising were chosen because they aim to control an emerging threat. Indeed, the need to curb online advertising has increased in step with the exponential growth of the virtual wildlife trade (Knowledge@Wharton, 2018). For purposes of identification and analysis, offense types selected for review were defined as follows:

- Illegal hunting is hunting without permission. Related penalties punish individuals for hunting both protected and unprotected species. The review excluded the criminalization of hunting 
in particular areas (such as national parks) and of certain hunting methods (such as night lighting), as these violations are often identified in separate provisions and typically have higher penalties due to their more serious nature. A recent ten-year study led by the Wildlife Conservation Society found that $80 \%$ of gorillas and chimpanzees in western equatorial Africa live outside protected areas (Strindberg et al., 2018); based on these findings, the analysis did not apply further spatial considerations.

- Illegal domestic sale is the illegal sale, trade or offer for sale (excluding acts that constitute advertising, which is defined separately) of any protected or unprotected live or dead wildlife, including their parts and derivatives. Captured great apes and gibbons largely supply the wild meat trade, the pet trade and substandard zoos (Clough and May, 2018). In all cases, related prohibitions target an active market.

- Illegal advertisement of wildlife products is any offense related to restrictions on advertising protected, unprotected, live and dead wildlife, including their parts and derivatives, be it in print, online or through other means of communication, such as radio or television.

For each of the three selected offense types, Legal Atlas researchers examined relevant provisions and recorded detailed information on five critical elements:

- whether and how liability of wildlife offenders differs based on their status (individuals, corporations or government officials);

- the applicability of imposable penalty types-be they monetary, administrative or prison terms;

- the degree to which intent requirements (such as knowledge or negligence) and aggravating circumstances are considered the basis for higher penalties;

- the criteria used to determine fine levels; and

- the maximum prison terms.

The analysis did not cover other potentially applicable penalties, forms of liability or procedural requirements contained in criminal procedure legislation.

\section{Differential Liability by Offender Status}

The analysis focused on three generic categories of offender: natural persons or individuals; legal persons (any entity recognized by law); and government officials. Some jurisdictions establish separate penalty levels for each of these categories in an effort to adapt the punishment to the type of offender and the degree of harm caused by the offender's activity. ${ }^{15}$

States that do not tailor liability to the type of criminal miss key opportunities to combat international criminal networks and domestic corruptive practices, which are often at the heart of illegal wildlife trade. Transnational organized criminal networks that are linked to the trade use corrupt government officials and companies in the financial, transportation and communications sectors. As the New York Times reports:

\footnotetext{
A secret ape pipeline runs from the lush forests of central Africa and Southeast Asia, through loosely policed ports in the developing world, terminating in wealthy homes and unscrupulous zoos thousands of miles away. The pipeline, documents show, is lubricated by corrupt officials (several have been arrested for falsifying export permits) and run by transnational criminal gangs (Gettleman, 2017).
}

To deter future wrongdoing, it is thus crucial that the prosecution of ape trade crime entail specialized administrative and 
criminal sanctions-such as the removal of corrupt customs officers or the confiscation of assets from implicated legal entities. The application of such sanctions requires differential liability, a step beyond the more traditional approaches that treat wildlife criminals solely as individuals and, typically, as poachers. Among the 17 analyzed countries, however, individual liability is the norm for all wildlife offenses; only a handful of countries impose different or higher penalties for legal persons and even fewer do so for civil servants (see Table 6.4). China is the only country that applies the disciplinary measures enshrined in its wildlife law to government officials who fail to conduct their professional duty in accordance with the law. For the most part, in other words, primary wildlife and criminal laws do not impose heightened forms of liability on the most important players in the ape trade business.

In addition to the tools reviewed in this study, a few others are gaining attention and have the potential to promote the use of differential liability in punishing wildlife crime. A recent Legal Atlas report on anti- money-laundering statutes, for example, documents separate and substantially higher punishments for legal persons and government officials involved in money laundering activities (Wingard and Pascual, 2019). ${ }^{16}$ The continued circulation of the proceeds of crimes recognized by such laws-which in many jurisdictions includes any crime and, therefore, all forms of illicit wildlife tradeconstitutes money laundering. While these laws do not solve the problem of wildlife crime, they do provide greater opportunities to convict wildlife traffickers with tougher penalties than those stipulated in many wildlife laws. Similarly, organized crime legislation, another criminal law instrument with substantially higher penalties, could be leveraged in the fight against wildlife crimes.

Figure 6.1 illustrates that Cameroon's fine levels for the offense of hunting protected species are significantly higher if the crime entails money laundering, and even higher if organized crime is involved. If individual poachers are prosecuted under Cameroon's wildlife legislation, they may be fined as little as US $\$ 80 .{ }^{17}$ If, however, investigations can prove that proceeds of the crime have been

TABLE 6.4

Differential Liability in Selected Wildlife Trade Crimes in 17 Ape Range States, 2018

\begin{tabular}{|c|c|c|c|c|c|c|c|}
\hline & Crime & Cambodia & Cameroon & China & DRC & Guinea & Indonesia \\
\hline \multirow[t]{3}{*}{ Individuals } & Illegal hunting & & & & & & \\
\hline & Illegal domestic sales & & $\mathbf{P}$ & & $\mathbf{P}$ & & \\
\hline & Advertising illegal products & & & & & & \\
\hline \multirow{2}{*}{ Legal entities } & Illegal domestic sales & & & & $P$ & & $\mathbf{P}$ \\
\hline & Advertising illegal products & & & & & & \\
\hline $\begin{array}{l}\text { Government } \\
\text { officials }\end{array}$ & Illegal hunting & $P$ & & & & & \\
\hline
\end{tabular}


laundered, then the anti-money-laundering statutes provide for fines as high as US\$17,000. If the prosecution can also prove that an organized criminal network was behind the money laundering, fines can reach US $\$ 35,000$ (Legal Atlas, 2018). ${ }^{18}$

\section{Penalties}

The legal sanctions that are available to combat the illegal wildlife trade include monetary fines, administrative sanctions and criminal penalties.

Monetary fines are imposed on guilty parties. Among the more common monetary penalties are fines and the forfeiture of the means-such as the tools and equipment used to commit a crime- and the proceeds, including the property and finances derived from the crime. Such fines are set, for example, in Viet Nam's decree on administrative penalties for forest-related violations (Decree No. 41/2017/ND-CP, 2017; Decree No. 157/2013/ND-CP, 2013, art. 21). Fines are intended to deter potential offenders, remove the capacity to commit further crime and deny the benefits of the crime to those

\section{FIGURE 6.1}

\section{Monetary Penalties for Illegal Hunting in Cameroon}

US\$85-350
Individuals
and legal
entities

entities

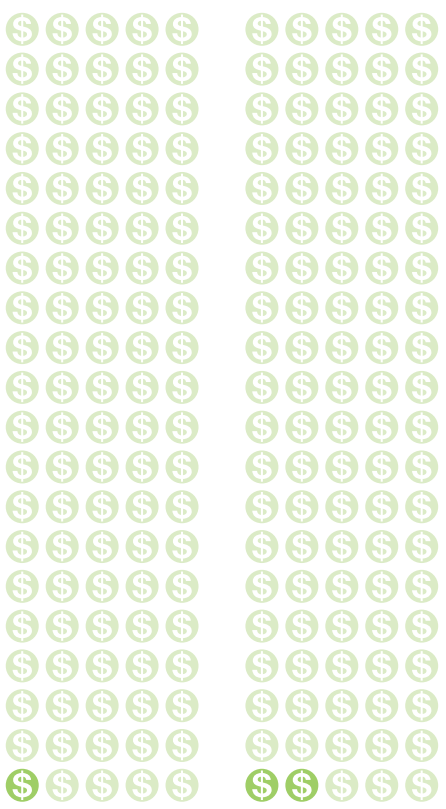

Sources: CEMAC (2016); Legal Atlas (2018)

US\$170-700
Government
officials

US $\$ 17,000$

If also

laundering proceeds of illegal hunting

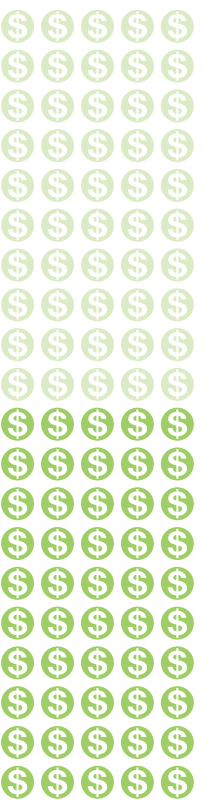

US $\$ 35,000$

If also operating within an organized criminal network

(4) (4) (5) (5) (5) (\$) (\$) (3) (\$) \$ (5) (\$) \$ \$ (5) (5) (5) (5) (5) (5) (\$) (5) (5) (5) (3) (5) (5) (5) (5) (5) (\$) \$\$ \$ (5) (5) (5) (\$) (\$) \$ (5) (3) (5) (3) (5) (\$) (\$) (5) (5) (5) \$ $\$$ (5) (\$) (\$) (5) (5) (5) (5) (3) \$ (\$) (\$) \$ \$ (\$) (5) (5) $\$$ (5) (3) (\$)

Key: Differential liability No liability or no differential liability $\odot$ Protected species only

\begin{tabular}{|c|c|c|c|c|c|c|c|c|c|c|}
\hline $\begin{array}{l}\text { lvory } \\
\text { Coast }\end{array}$ & $\begin{array}{l}\text { Lao } \\
\text { PDR }\end{array}$ & Liberia & Malaysia & Myanmar & Nigeria & $\begin{array}{l}\text { Republic } \\
\text { of Congo }\end{array}$ & Rwanda & Tanzania & Uganda & Viet Nam \\
\hline & & & $P$ & & & & & & & \\
\hline & & & $P$ & & & & & & $P$ & $\mathbf{P}$ \\
\hline & & & $P$ & & & & & & & \\
\hline & & $P$ & $P$ & & & & & & & \\
\hline & $P$ & & $P$ & & & & & & & $P$ \\
\hline & & & $\mathbf{P}$ & & & & & & & \\
\hline & & & & & & & & & & $P$ \\
\hline & $\mathbf{P}$ & & & & & & & & & $\mathbf{P}$ \\
\hline & & & & & & & & & & \\
\hline
\end{tabular}


involved. Other monetary penalties include compensation and restoration, both of which address the need to repair the damage caused; while Costa Rica's wildlife conservation law imposes such fines, it does not specify how values are to be determined (Ley de Conservación de la Vida Silvestre, 1992, art. 101).

This chapter uses the term "administrative penalty" to refer to any sanction that limits an offender's rights or position held in government, whether applied by an administrative or a criminal law. ${ }^{19}$ Among these sanctions are temporary and permanent bans on access to a resource, license suspensions and revocations, as well as suspension and removal from a government position. On the whole, such penalties are used to deny violators access to public benefits and positions. An example is Indonesia’s Environmental Protection and Management Law, which stipulates which types of administrative sanctions apply to environmental offenders (Republic of Indonesia, 2009, art. 76).

For the purposes of this review, criminal penalties are limited to two types of sanctions: monetary fines and the restriction of freedom, including the imposition of prison terms and community service orders. ${ }^{20}$ For the most part, criminal sanctions are intended to deter criminals from committing crimes

TABLE 6.5

\section{Penalty Types for Selected Wildlife Trade Crimes in 17 Ape Range States, 2018}

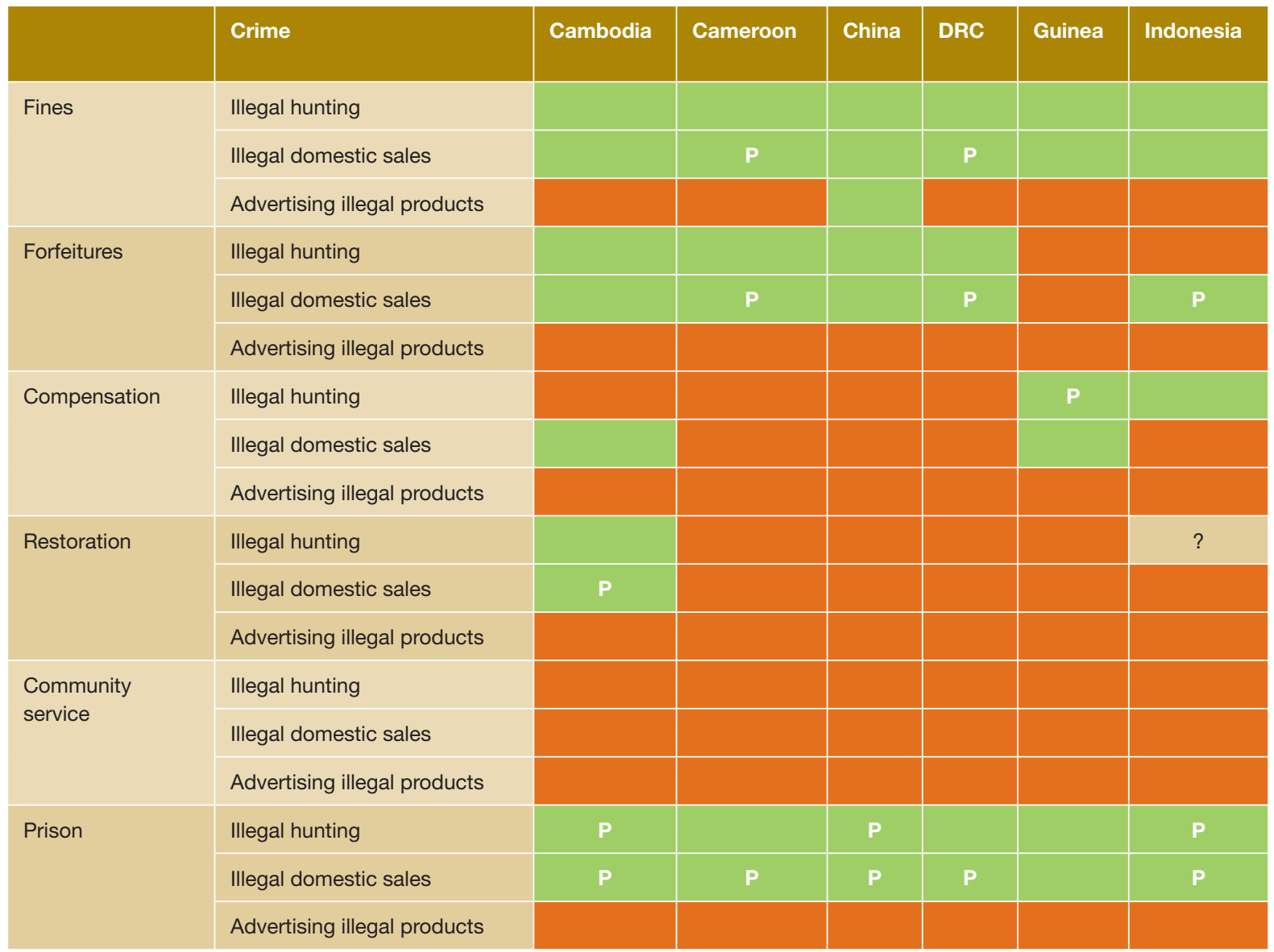


before they happen, remove criminals from society to minimize the threat they pose, and rehabilitate criminals.

Table 6.5 presents the types of administrative and criminal penalties that the countries under review impose for the three selected offenses. Fines and prison sentences are well represented across all jurisdictions, although they vary depending on the protection status of the relevant species. Community service is not explicitly mentioned for any of the selected crimes in any of the 17 countries.

The differences based on species status have implications for great apes and gibbons. They are listed as protected in almost all jurisdictions, yet three countries omit some species-Cambodia, Lao PDR and Viet Nam. Consequently, weaker deterrents are in place with respect to three specific ape species, which may thus be more vulnerable to being hunted and traded. In Lao PDR, the lack of prison penalties for domestic ape sales affects three species of gibbon: the northern yellowcheeked crested gibbon (Nomascus annamensis), southern white-cheeked crested gibbon (Nomascus siki) and southern yellow-cheeked crested gibbon (Nomascus gabriellae). In Cambodia and Viet Nam, which apply prison terms only for the hunting of protected species, unlisted gibbons are similarly exposed

Key: Uses Does not use Protected species only

\begin{tabular}{|c|c|c|c|c|c|c|c|c|c|c|}
\hline $\begin{array}{l}\text { lvory } \\
\text { Coast }\end{array}$ & $\begin{array}{l}\text { Lao } \\
\text { PDR }\end{array}$ & Liberia & Malaysia & Myanmar & Nigeria & $\begin{array}{l}\text { Republic } \\
\text { of Congo }\end{array}$ & Rwanda & Tanzania & Uganda & Viet Nam \\
\hline & & & $\mathbf{P}$ & & & & & & & \\
\hline & & & P & & & & & & $P$ & $\mathbf{P}$ \\
\hline & & & $P$ & & & & & & & \\
\hline & & $P$ & $P$ & & & & & & & \\
\hline & & & $P$ & & & & & & $P$ & $P$ \\
\hline & & & P & & & & & & & \\
\hline & & $P$ & & & & & & & & \\
\hline $\mathbf{P}$ & & & & & & & & & & \\
\hline & & & & & & & & & & \\
\hline & & & & & & & & & & \\
\hline & & & & & & & & & & \\
\hline & & & & & & & & & & \\
\hline & & & & & & & & & & \\
\hline & & & & & & & & & & \\
\hline & & & & & & & & & & \\
\hline & $P$ & & $P$ & & $P$ & & & & & \\
\hline & & & $\mathbf{P}$ & $P$ & $P$ & & $\mathbf{P}$ & & P & $\mathbf{P}$ \\
\hline & & & $P$ & & & & & & & \\
\hline
\end{tabular}


to higher risks. Such is the case for the northern yellow-cheeked crested gibbon and southern yellow-cheeked crested gibbon in Cambodia, and for the northern yellowcheeked crested gibbon and southern whitecheeked crested gibbon in Viet Nam.

\section{Intent Requirements and Aggravating Circumstances}

Intent requirements and aggravating circumstances are also common elements in criminal provisions (see Table 6.6). They are an acknowledgment that as not all crimes involve the same level of guilt, they should not be treated equally.

Knowledge requirements are typically used to achieve one of two goals: 1 ) to lower the intentionality - and therefore the burden of proof-required for liability to be imposed; and 2) to determine penalties based on the level of criminal intent, such that lower pen- alties are imposed for negligence (including gross negligence) and higher ones for intentionality. Indonesia and Liberia are the only countries that differentiate between negligence and intentionality in their wildlife laws, increasing the economic penalties if an offense has been committed intentionally. It is unlikely that negligence plays much of a role in the great apes and gibbon trade, as involvement in the trade, by its very nature, is an intentional act-it is highly improbable that anyone would inadvertently sell a live chimpanzee. Negligence could be a factor in wild meat trade, however; correspondingly, intentionality can be considered a justification for raising fines and penalties, as applicable.

Aggravating circumstances, in contrast, are egregious aspects of a crime that can be used to increase fines and penalties. Among the countries under review, repeat offenses (recidivism) are the most common aggravat-

TABLE 6.6

\section{Knowledge Requirements and Aggravating Circumstances in Wildlife Trade Crimes in 17 Ape Range} States, 2018

\begin{tabular}{|c|c|c|c|c|c|c|c|}
\hline & Crime & Cambodia & Cameroon & China & DRC & Guinea & Indonesia \\
\hline \multirow[t]{3}{*}{ Gross negligence } & Illegal hunting & & & & & & \\
\hline & Illegal domestic sales & & & & & & \\
\hline & Advertising illegal products & & & & & & \\
\hline \multirow[t]{3}{*}{ Intentionality } & Illegal hunting & & & & & & \\
\hline & Illegal domestic sales & & & & & & $\mathbf{P}$ \\
\hline & Advertising illegal products & & & & & & \\
\hline \multirow[t]{3}{*}{ Recidivism } & Illegal hunting & & & & & & \\
\hline & Illegal domestic sales & & $\mathbf{P}$ & & P & & \\
\hline & Advertising illegal products & & & & & & \\
\hline \multirow[t]{3}{*}{ Large amounts } & Illegal hunting & & & & & & \\
\hline & Illegal domestic sales & & & & & & \\
\hline & Advertising illegal products & & & & & & \\
\hline
\end{tabular}


ing circumstances, while high volume and value thresholds are factors in only two of the reviewed jurisdictions, Malaysia and Viet Nam. As countries make inconsistent use of aggravating circumstances for the three selected offenses, their legal approaches are characterized by significant gaps. States that exclude the use of recidivism in their wildlife laws - in this review, Indonesia, Malaysia, Myanmar and Tanzania-exhibit the greatest regulatory gaps. Another weakness relates to the inconsistent application of aggravating circumstances across wildlife crimes. Such is the case in the DRC, which uses different laws to set out offense types, thereby creating divergent legal approaches. A less consequential limitation is the exclusive use of aggravating circumstances in offenses against protected species, an approach employed by Viet Nam. Only 6 of the 17 reviewed jurisdictions treat repeat offenses as an aggravating circumstance for all offenses contained in their wildlife laws: Cambodia, Cameroon, Ivory Coast, Guinea, Nigeria and Uganda.

On the whole, repeat offenses are probably the norm and not the exception, as indicated by the high rate of great ape and gibbon removals, as well as the involvement of criminal networks, corrupt officials and established trade pipelines (UNODC, 2016). Uniform penalty levels can only have a general effect, as they are not directed at any particular offender. In contrast, penalties that are higher for repeat offenders can help to deter individuals who are likely to commit wildlife crimes. Among the 17 countries under review, there is certainly room to expand the use of legal tools to deter people from engaging in the ape trade.

\section{Calculating Fines}

Ensuring that fine levels for wildlife crime have an appropriate deterrence value is a

Key: Penalty $\bigcirc$ No Penalty Protected species only

\begin{tabular}{|c|c|c|c|c|c|c|c|c|c|c|}
\hline $\begin{array}{l}\text { lvory } \\
\text { Coast }\end{array}$ & $\begin{array}{l}\text { Lao } \\
\text { PDR }\end{array}$ & Liberia & Malaysia & Myanmar & Nigeria & $\begin{array}{l}\text { Republic } \\
\text { of Congo }\end{array}$ & Rwanda & Tanzania & Uganda & Viet Nam \\
\hline & & $P$ & & & & & & & & \\
\hline & & & & & & & & & & \\
\hline & & & & & & & & & & \\
\hline & & & & & & & & & & \\
\hline & & & & & & & & & & \\
\hline & & & & & & & & & & \\
\hline & & & & & & & P & & & P \\
\hline & & & & & & & & & P & $\mathbf{P}$ \\
\hline & & & & & & & & & & \\
\hline & & & $P$ & & & & & & & $\mathbf{P}$ \\
\hline & & & & & & & & & & P \\
\hline & & & & & & & & & & \\
\hline
\end{tabular}


sophisticated and complex exercise that is not yet supported by global standards. That said, three general guidelines are well established. The first is that fines should be high enough to ensure that the perceived risk or cost of being fined is higher than the perceived benefit. The second guideline is that fines should eliminate the financial gain of a crime, meaning that they should correspond to the potential or actual market value of the trafficked goods. Proportionality to the harm caused is the third guideline (OECD, 2009). In the context of the illegal wildlife trade, the ecological damage inflicted by any given take varies according to the season and the protection status, age, number and sex of the animals removed from their habitat.

The review of financial penalties for the three selected crime types-illegal hunting, selling and advertising-demonstrates that there is significant opportunity to develop greater deterrent value. Although most reviewed states impose fines that take account of a trafficked animal's protection status-only Cameroon and Ivory Coast do not-few factor in other relevant criteria. Only 7 of the 17 countries adjust fines to reflect the economic harm or ecological damage caused by the three selected wild-

TABLE 6.7

\section{Fine Criteria Used in Wildlife Trade Crimes in 17 Ape Range States, 2018}

\begin{tabular}{|c|c|c|c|}
\hline \multirow[t]{2}{*}{ Country } & \multicolumn{3}{|c|}{$\begin{array}{l}\text { Wildlife crime penalty criteria } \\
\text { Applied Not applied }\end{array}$} \\
\hline & Protection status & $\begin{array}{l}\text { Economic damage } \\
\text { (market or damage values) }\end{array}$ & $\begin{array}{l}\text { Ecological damage } \\
\text { (wildlife amount, age and sex) }\end{array}$ \\
\hline \multicolumn{4}{|c|}{ Cambodia } \\
\hline \multicolumn{4}{|l|}{ China } \\
\hline \multicolumn{4}{|l|}{ DRC } \\
\hline \multicolumn{4}{|l|}{ Guinea } \\
\hline \multicolumn{4}{|l|}{ Indonesia } \\
\hline \multicolumn{4}{|l|}{ Liberia } \\
\hline \multicolumn{4}{|l|}{ Malaysia } \\
\hline \multicolumn{4}{|l|}{ Myanmar } \\
\hline \multicolumn{4}{|l|}{ Nigeria } \\
\hline \multicolumn{4}{|c|}{ Republic of Congo } \\
\hline \multicolumn{4}{|l|}{ Rwanda } \\
\hline
\end{tabular}


life crimes. Moreover, only Malaysia and Viet Nam set their fines based on the amount, sex and age of the hunted, traded and advertised wildlife (see Table 6.7).

\section{Prison Terms}

There is no global consensus on what the national minimum prison sentence should be for wildlife crimes. For illicit trafficking of endangered species, the United Nations Convention against Transnational Organized Crime (UNTOC) recommends establishing these offenses as "serious crimes"-meaning that they should carry a maximum prison sentence of at least four years (UNGA, 2000, arts. 2(b); 5).

As noted above, few countries under review have criminalized the hunting, sale or advertising of wildlife that is not on their national lists of protected species; individuals who engage in such activities are thus less likely to be served prison sentences than those who target protected wildlife. With the exception of unlisted gibbons in three countries, as detailed above, all apes are recognized as protected species in the domestic legislation of the 17 countries under review (see Table 6.2). Table 6.8 illustrates the variations in maximum prison terms for illegal hunting. For the most part, countries meet the UNTOC threshold of a four-year penalty; only four countries fail in this regard-Cameroon, Ivory Coast, Guinea and Nigeria-with terms that are substantially shorter. Viet Nam imposes the highest prison term: 15 years.

Among the countries under review, prison terms for illegal sales are largely akin to those for illegal hunting. Only three jurisdictions impose different terms for illegal sales: the penalty is lower in Liberia (1 year rather than 4) and higher in Malaysia and Tanzania (7 years rather than 6 and 30 years rather than 10, respectively). Malaysia is the only country that imposes
TABLE 6.8

Maximum Prison Terms for Illegal Hunting of Protected Species in 17 Ape Range States, 2018

\begin{tabular}{|c|c|c|c|c|c|c|}
\hline \multirow[t]{2}{*}{ Country } & \multicolumn{6}{|c|}{ Maximum prison term (years) } \\
\hline & $<1$ & 1 & 4 & 5 & 10 & 15 \\
\hline Cambodia & & & & & $\checkmark$ & \\
\hline Cameroon & $\checkmark$ & & & & & \\
\hline China & & & & & $\checkmark$ & \\
\hline DRC & & & & & $\checkmark$ & \\
\hline Guinea & & $\checkmark$ & & & & \\
\hline Indonesia & & & & $\checkmark$ & & \\
\hline Ivory Coast & & $\checkmark$ & & & & \\
\hline Lao PDR & & & & $\checkmark$ & & \\
\hline Liberia & & & $\checkmark$ & & & \\
\hline Malaysia & & & & $\checkmark$ & & \\
\hline Myanmar & & & & & $\checkmark$ & \\
\hline Nigeria & & $\checkmark$ & & & & \\
\hline Republic of Congo & & & & $\checkmark$ & & \\
\hline Rwanda & & & & & $\checkmark$ & \\
\hline Tanzania & & & & & $\checkmark$ & \\
\hline Uganda & & & & $\checkmark$ & & \\
\hline Viet Nam & & & & & & $\checkmark$ \\
\hline
\end{tabular}

Source: Rodriguez et al. (2019)

prison terms for illegal advertising (seven years). The use of prison terms indicates that states generally focus on the beginning of the supply chain, ignoring the serious role played by criminal networks in the marketing and sale of endangered species. These legal gaps expose both great apes and gibbons to higher risks.

\section{Trend Analysis: Whose Authority Is It Anyway?}

Effective law enforcement requires a stable and transparent structure of national authorities. Hunters and other stakeholders need 


66 The shortage
of checks and
balances currently
endangers the
transparency,
functionality and
purpose of
CITES entities,
rendering the
dismissal of
scientific evidence
and the abuse
of power more
likely. 99

clarity regarding legal requirements on them, including where and how often they must apply for permits or licenses. Field officers need to know what their powers and limits are, with which offices they must work and with whom they need to share information. A lack of awareness about such obligations can create significant loopholes that can be exploited, compromising conservation and enforcement goals.

The kind of clarity that would help is not necessarily the natural product of the legislative process, however. One of the common characteristics of complex domestic legal frameworks is an abundance of authorities that overlap or share management and enforcement powers with respect to a particular issue. The cumulative result of multiple laws written at different times for different reasons, a legal framework pertaining to the protection of wildlife or any other issue can comprise elements that are not expressly related to that issue, such as criminal codes, criminal procedure codes and state security laws. Adding to the confusion is the periodic reorganization of management and enforcement structures in line with political events. In some jurisdictions, these changes can be so profound and frequent that legislative drafting rules prohibit the specific naming of any particular institution in the delegation of power. Instead, legislators use generic names so that the reorganization of the political structure does not require amendments of legislation (Rosenbaum, 2007).

In assessing the legislative frameworks, this study reveals that each country under review has more than six different enforcement agencies and more than five different management authorities with legal competencies related to the wildlife trade. In the most extreme case-that of Viet Nam13 different institutions share enforcement responsibilities. In some instances, the same authority holds both managerial and enforce- ment responsibilities. In Viet Nam, for example, the ministry of agriculture serves as the CITES management authority, but it also has inspection powers and the authority to revoke CITES permits. In all countries, the legal framework is a complex ecosystem of ministries, institutions, research bodies and enforcement authorities, such as customs, national police, military and specific wildlife enforcement bodies.

Having so many different authorities in charge of individual aspects of illegal wildlife trade is not technically inappropriate. In fact, it is to be expected given the multifaceted nature of the trade. Moving along the supply chain, the enforcement of related laws can involve rangers, specialized wildlife forces, police, customs authorities, CITES management authorities, and the judicial system, including its investigators, prosecutors and courts. In federal structures, there may even be different levels of law enforcement at which national and regional entities share competencies, as is the case in Malaysia.

The involvement of multiple institutions does, however, place a premium on coordination and sometimes makes it difficult to understand exactly who is responsible for what. By and large, the reviewed laws are short on details, defining neither formal structures for coordination, nor the exchange of information or data. One of the few exceptions is the legislation of Nigeria, which specifically tasks its National Environmental Standards and Regulations Enforcement Agency with "coordination and liaison with relevant stakeholders" (NESREA, 2007, art. 2). Malaysia confers responsibility for the national coordination of CITES enforcement on its "lead" CITES management authority, the Ministry of Water, Land and Natural Resources (Laws of Malaysia, 2008, art. 5).

Particularly important to the great apes and gibbon trade - and a critical area in law 
-is the inclusion of the institutional check and balance required by CITES for the scientific and management authorities (CITES, 2007a). Pursuant to CITES, the two types of authorities must be independent from each other; the scientific authority is to hold the power to veto management authority actions, such as draft CITES legislation and export permits that may endanger the survival of a particular species. Only nine of the jurisdictions under review maintain the required independence between these authorities-Cameroon, China, Guinea, Indonesia, Ivory Coast, Lao PDR, Liberia, Uganda and Viet Nam; the other eight do not. In at least five jurisdictions, both authorities are hosted in the same ministry (Cambodia, Malaysia, Myanmar, the Republic of Congo and Rwanda), while in Nigeria and Tanzania, the management authority acts as a chair or coordinator of external entities comprising the scientific authority. More importantly, the required veto power over CITES draft legislation is missing in all countries.

The shortage of checks and balances currently endangers the transparency, functionality and purpose of CITES entities, rendering the dismissal of scientific evidence and the abuse of power more likely. Although all international commercial trade in great apes and gibbons is prohibited by CITES, trade for non-commercial purposes is still possible and must pass through this system. In this context, legal loopholes can affect the legitimacy of trade and further jeopardize species survival.

\section{National Frameworks: Conclusions}

By itself, the law cannot solve the problem of trade in great apes and gibbons. If appropriately developed and enforced within a functioning legal framework, however, it can play a critical role in addressing the complex market realities that underlie the illegal wildlife trade. Developing the law would involve identifying and criminalizing the numerous distinct activities that together constitute the wildlife supply chain -from poaching, transportation, processing, storage, advertising, and domestic and foreign trade, through to possession, exhibition and experimentation. As discussed above, the review of 17 ape range states indicates that the criminalization of domestic and foreign trade of illegally taken species is common, but that more can be done to close the regulatory gaps that leave wildlife exposed to harm.

The control of the transnational wildlife trade is not solely a function of CITES implementation. States can avail themselves of a number of legal tools to enhance domestic enforcement opportunities to address the trafficking of internationally sourced wildlife. Accordingly, some countries are recognizing both native and non-native species as domestically protected. This simple legal act has the potential to ease enforcement burdens and increase opportunities for enforcement in cases where protected wildlife has been trafficked across a border. States can also use legislation to focus on the international criminal networks and corruption that fuel trade across countries. Doing so is likely to involve expanding laws to cover not only poachers, but also legal entities, criminal networks and government officials involved in the trade. The use of related economic and legal tools-such as organized crime and anti-money-laundering statutes - can also translate into greater deterrence values and can help to target implicated entities that would otherwise escape liability.

Finally, a host of management and enforcement authorities come into play as illegal wildlife is moved from natural habitats to the market, yet many of them have no direct relation to or training in wildlife 
Photo: When a great ape or gibbon is taken illegally from the wild, it is important that all consecutive actions also be expressly prohibited by law, from transportation, through storage, processing, exhibition, experimentation, advertising, domestic and foreign trade, use and possession. Screenshot courtesy of PEGAS. issues. Just as legislators can target all points along the trade chain, so too can they ensure that all stakeholder activities are appropriately managed, specifically by establishing formal mechanisms for effective coordination.

All told, maximizing opportunities to combat the ape trade requires the development of the law, in particular through the use of legal tools that target all activities and actors along the illegal supply chain.

\section{International Frameworks}

Individuals who transport apes, or their body parts or derivatives, across national boundaries are subject-at least potentially - to a range of laws and regulations that are designed to prevent trade in protected species and to promote wildlife conservation. This section reviews the main agreements and organizations that are most relevant to the illegal trade in apes.

\section{CITES}

\section{The CITES Structure}

The main international agreement of relevance is the 1973 Convention on International Trade in Endangered Species of Wild Fauna and Flora. CITES, which entered into force in 1975 and had 183 parties as of January 2020 , aims to protect wildlife from overexploitation by controlling international trade, under a system of import and export permits (CITES, n.d.-k).

Wildlife protected by CITES-currently about 5,800 species of animals and 30,000 species of plants (CITES, n.d.-d) - appears in different appendices:

- Appendix I lists species that are threatened with extinction;

- Appendix II lists species that are not necessarily threatened with extinction now but may become so unless trade in them is subject to strict regulation; and

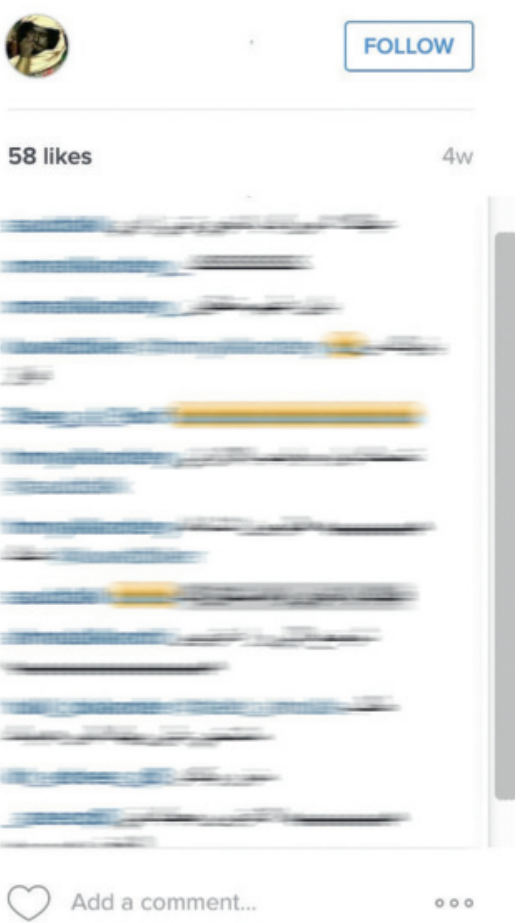

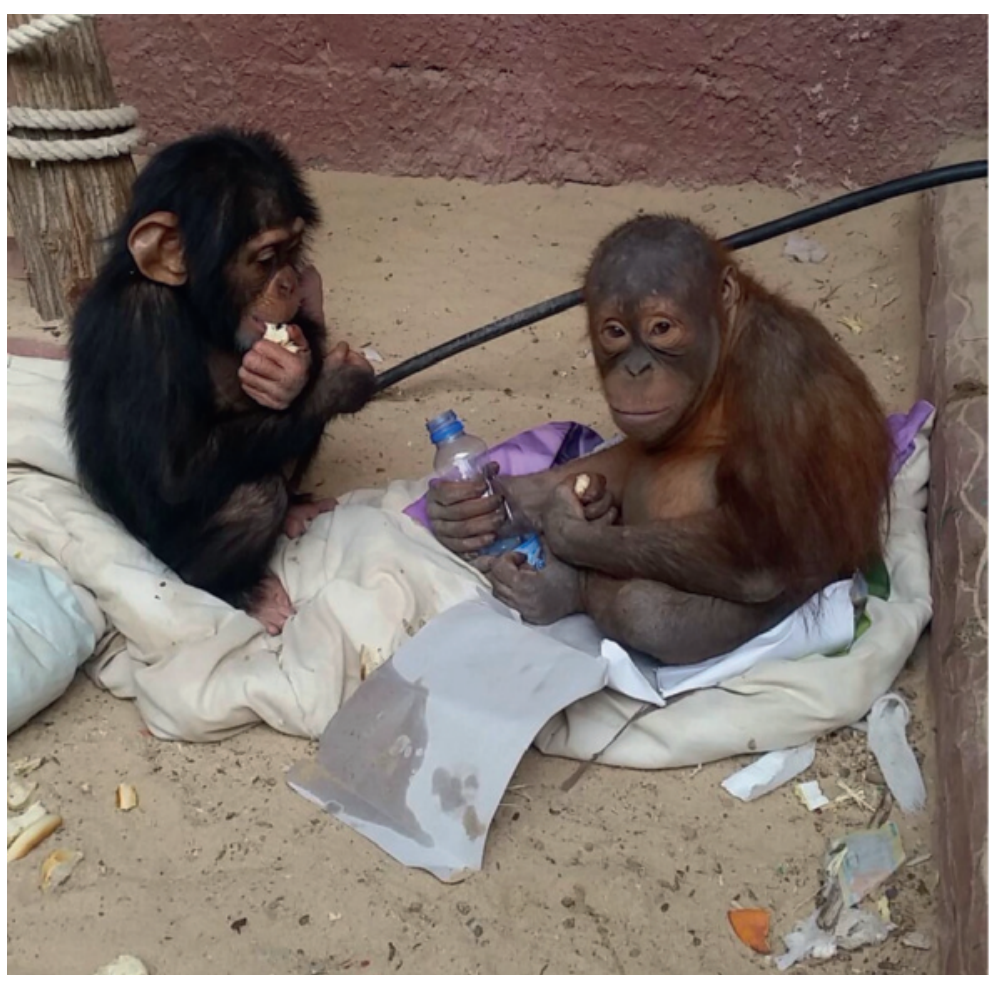


- Appendix III includes species listed unilaterally by parties that wish to regulate their trade and want to signal the need for international cooperation (CITES, n.d.-g).

Amendments to Appendices I and II are adopted by the CITES Conference of the Parties (CoP); individual parties may unilaterally place species on Appendix III at any time (CITES, n.d.-g).

Appendix I is effectively a black list that prohibits primarily commercial trade in endangered species, including all species of gibbon and great ape-bonobos, chimpanzees, gorillas and orangutans. Exceptions from and variations on these requirements apply to individuals, parts or derivatives that:

are transiting or being transshipped "while in Customs control" of a CITES member state;

- are personal or household effects, including pets;

nere acquired prior to the species listing under CITES;

- were bred in captivity for commercial purposes or for non-commercial trade between scientists or scientific institutions; or

- are part of a traveling zoo, circus or other traveling exhibition (CITES, 1973, art. VII).

Under these provisions, entities and individuals who trade in listed specimens must obtain both export and import permits; certificates are also required for re-export. All CITES parties designate one or more management authorities to administer the permit system and one or more scientific authorities to advise the management authority on the effects of trade on the status of the species. A management authority may only issue permits if two requirements are met. First, a scientific authority must issue a so-called "non-detriment" finding - a conclusion that the export of the specimen will not have a negative impact on the survival of the species in the wild. Second, the management authority must be satisfied that the specimens have been acquired legally and that the trade is not for primarily commercial purposes.

Various requirements apply to the issue of permits. For example, a separate permit is required for each consignment, and export permits are valid for a maximum of 6 months, while import permits expire after 12 months. Permits and certificates must include statements of the source of specimens-that is, whether they are wild-caught, captive-bred, ranched or artificially propagated-and the intended purpose of the import, such as commercial, scientific or educational. The requirements that apply to trade in Appendix II and III species are less strict.

The CITES CoP is the main decisionmaking body; its powers include adding species to and removing them from both Appendices I and II. The CITES Standing Committee, which normally meets once a year, provides policy guidance to the Secretariat concerning CITES implementation, coordinates and oversees the work of other committees and working groups, and administers the non-compliance procedure, through which recommendations can be issued for the suspension of trade in some or all listed species with parties not complying with CITES requirements (CITES, 2019a, n.d.-b, n.d.-j).

The CITES framework provides a potentially effective means of regulating the trade in endangered and threatened species of wildlife, but in practice it suffers from several weaknesses. The enforcement of CITES controls, both within a country and in regard to suspensions of trade between parties and non-complying parties, rests on parties' management authorities. In many cases these 
bodies do not operate effectively, typically because of insufficient capacity, a lack of willingness, corruption or, sometimes, the intricacies of international diplomacy. Permit fraud is a constant problem; especially where the traded specimens are of high value, there are incentives for fraud, theft and corruption in issuing permits, stealing or buying blank ones, or tampering with them while in use (such as by changing the numbers of specimens covered). In many cases, trade in listed specimens has been carried out for ostensibly scientific-but in reality commercialpurposes; similarly, wild-caught specimens have been falsely identified as hailing from facilities that are supposedly engaged in captive breeding (Elliott and Schaedla, 2016; Lavorgna et al., 2018; OECD, 2012; see Box 6.1).

The UN Environment World Conservation Monitoring Centre (UNEP-WCMC) maintains a database of issued import and export permits, derived from annual reports from CITES parties, but it does not systematically cross-check the documents against each other (UNEP-WCMC, n.d.). ${ }^{21}$ Nor are the permits systematically checked against what is actually in the shipments they accompany; customs officers are not typically able to identify species as protected, particularly given the vast number listed in the CITES appendices. Claims that trade is being carried out for scientific purposes or that specimens are captive-bred frequently go unchecked by the management or customs authorities in both exporting and importing states. Many countries lack the capacity to operate the system correctly, with insufficient numbers of adequately trained or paid staff, and a lack of basic equipment; many states that do have adequate capacity simply do not operate the controls rigorously (Elliott and Schaedla, 2016; Lavorgna et al., 2018; OECD, 2012).

The CITES bodies have attempted to address these problems in various ways. The
CITES Secretariat provides training and capacity building assistance; it also coordinates review missions to parties to examine their implementation of the agreement (CITES, n.d.-c). In addition, it carries out regular reviews of the status of trade in particular species. Work is currently under way to define more carefully the meaning of "legal acquisition" - that is, the requirement that specimens to be traded must have been legally caught or acquired. In 2015, against the background of a steady rise in the trade in captive-bred specimens-whose number now exceeds that of specimens traded as wild-caught - the 17 th CITES CoP ( $\mathrm{CoP} 17)$ asked the Standing Committee to assess and develop solutions to the problems associated with trade in captive-bred specimens (CITES, 2015b, n.d.-a). CITES parties register commercial captive-breeding facilities in a database maintained by the CITES Secretariat, yet facilities do not need to be registered if they breed animals only for zoos or scientific purposes. The Secretariat's investigations into some of these facilities have revealed problems such as limited access and misuse of source codes (TRAFFIC, 2016).

A number of these problems could be addressed through the use of electronic permit systems rather than the paper systems that remain dominant; digitalization would help to reduce the opportunities for fraud and tampering, while facilitating monitoring of trade and communication between management authorities. In 2005, the CITES parties established a working group to explore the use of information technology, and several countries have developed and piloted, or fully implemented, electronic systems (CITES, n.d.-f). In collaboration with the World Customs Organization, the CITES Secretariat published a toolkit of common forms, protocols and standards in 2010 and updated it in 2013 (CITES, 2013a). In 2015, $\mathrm{CoP}_{17}$ decided to re-establish the working group to revise the existing docu- 
ments and develop new standards and tools (CITES, n.d.-f).

\section{CITES and Apes}

As noted above, all the species of ape are listed in CITES Appendix I but, as described in this volume's Introduction, there are several ways in which CITES controls can be evaded to facilitate illegal trade. Specimens can simply be smuggled across borders without any CITES permits. Even if permits have been issued, traders often abuse the various exceptions that allow trade in Appendix I species, as noted above. Management authorities in some countries have issued export permits stating that specimens were bred in captive-breeding facilities without checking whether the named facilities even exist (see Box 6.1). Similarly, management authorities in some importing countries have issued import permits claiming that specimens are destined for zoos or scientific purposes, even though the animals are actually intended for commercial use (PEGAS, 2017, n.d.).

Apes have been discussed at many CITES CoPs and meetings of the Standing Committee. In 2004, CoP13 passed Resolution 13.4, which deals specifically with great apes and calls on CITES parties and other bodies to take a series of measures on law enforcement and conservation (CITES, 2013b). ${ }^{22}$ Nevertheless, NGOs often argue that not enough attention is being paid to the topic, and that the relatively low number of reported seizures of trafficked great apes is a reflection of inadequate law enforcement efforts. ${ }^{23}$ In 2015, under Decision 17.232, $\mathrm{CoP}_{17}$ directed the Secretariat to produce a report on the status of great apes and the relative impact of illegal trade and other pressures on their status, for consideration by the Standing Committee (CITES, 2017b).

GRASP, IUCN and other experts produced the requested report. In October 2018,
B0X 6.1

\section{Permit Fraud in Guinea: A Key to Supplying Apes to China's Zoos}

From 2007 onwards, chimpanzees were exported from Guinea to China under apparently valid CITES permits that indicated that the animals were captive-bred. Investigations by non-governmental organizations (NGOs) and private individuals revealed that, by 2013, at least 138 chimpanzees and 10 gorillas had been exported via travel routes established by Chinese development companies. As no captive breeding facility existed in Guinea, investigators suspected that the apes had been taken from Cameroon, Ivory Coast, Liberia, the Republic of Congo or other countries in the region, in addition to Guinea (Stiles et al., 2013). Further evidence suggested that the export of apes had been going on for years - to China, Russia, Egypt and other Middle Eastern countries (PEGAS, n.d.).

In early 2011 the CITES Secretariat responded to reports from NGOs and others by expressing concerns about this trade to the relevant management authorities, including those in China and Guinea. Dissatisfied with the response, the Secretariat set up a mission to the country, which, in September 2011, found that 69 chimpanzees had been taken out of the country during the previous year, destined for Chinese zoos or safari parks. Based on the findings made during the mission, the Secretariat issued a notification to CITES parties, highlighting concerns regarding the validity of the permits and pointing out that there was no-and that there had never been any-commercial captive breeding of specimens of CITES-listed species in Guinea (CITES, 2015a).

In 2013, after Guinea failed to respond to the Secretariat's request to improve its procedures for issuing permits, the Standing Committee recommended that all commercial trade in CITES-listed species with Guinea be suspended; this suspension remains in force. In 2015 the head of Guinea's CITES management authority was arrested for his suspected role in corrupt and fraudulent actions in the issuance of CITES export permits. Although convicted and sentenced to 18 months in prison, he was pardoned by the country's president (PEGAS, 2017).

The case illustrates the scope-and the limitations-of CITES. While the Secretariat and the Standing Committee responded to the concerns raised by NGOs and others, they are not themselves enforcement agencies; they rely on the national management authorities to ensure that the permit system is correctly implemented. While the Guinean management authority should never have issued the export permits, the Chinese management authority should equally have queried their authenticity; no captive breeding facilities exist in Guinea. In addition, many-and perhaps all-of the chimpanzees ended up in amusement and safari parks; that is, they were imported for commercial, not scientific, purposes, which is further complicated by the status afforded such establishments in the country (see Chapter 4). Since the animals were illegally transferred, they should have been confiscated and repatriated. In addition, although China subsequently suspended imports of apes from Guinea, information in the CITES Trade Database suggests that it simply switched to importing from other countries (CITES, n.d.-e). In July 2018 correspondence was revealed from Chinese zoos to the environment minister of the Democratic Republic of Congo-which has no captive-breeding facilities either-requesting exports of mountain gorillas (Gorilla beringei beringei), bonobos (Pan paniscus), chimpanzees and other animals (Summers, 2018). 
Photo: A 2018 report to CITES identified the main threats to the survival of great apes as habitat loss, degradation and fragmentation, infectious disease, wild meat poaching, indiscriminate poaching, and deliberate killing due to conflicts over land. Confiscated chimpanzee carcass, following arrest of traders, Douala, Cameroon. (C) LAGA and The EAGLE Network at its 7oth meeting, the Standing Committee discussed the findings, including the latest information available on the distribution of great apes and their population changes over time. The report identifies the main threats to their survival as habitat loss, degradation and fragmentation; infectious disease; wild meat hunting and indiscriminate poaching; and deliberate killing due to conflicts over land. It concludes that the illegal international trade of great apes mainly involves wild meat, and mostly between neighboring countries. This type of trade tends to be less well researched and more difficult to detect and control than transcontinental trade. It also characterizes illegal trafficking of live orphans as primarily a by-product of the wild meat trade; in fact, it mentions the Guinea case outlined in Box 6.1 as the only example of great apes being targeted for capture and subsequent trade (CITES, 2018a). Some experts have questioned this finding, arguing that it underestimates the extent and drivers of illegal trade in live apes. ${ }^{24}$

While the report recognizes improvements in law enforcement efforts in some countries-including the spread of the Eco Activists for Governance and Law Enforcement (EAGLE) network of investigators and activists-it concludes that law enforcement efforts alone would be insufficient to halt illegal trafficking in live great apes or their body parts (CITES, 2018a; EAGLE, n.d.). It sets out 14 recommendations, including, for CITES parties, improvements in their national legal frameworks, law enforcement and data collection efforts; the adoption of transboundary agreements and collaborative judiciary proceedings; the introduction of requirements on private actors in the energy, extractive and agricultural sectors to minimize the impact of their operations on great ape populations and habitats; and efforts to promote alternatives to wild meat (CITES, 2018a). It also recommends rejecting any

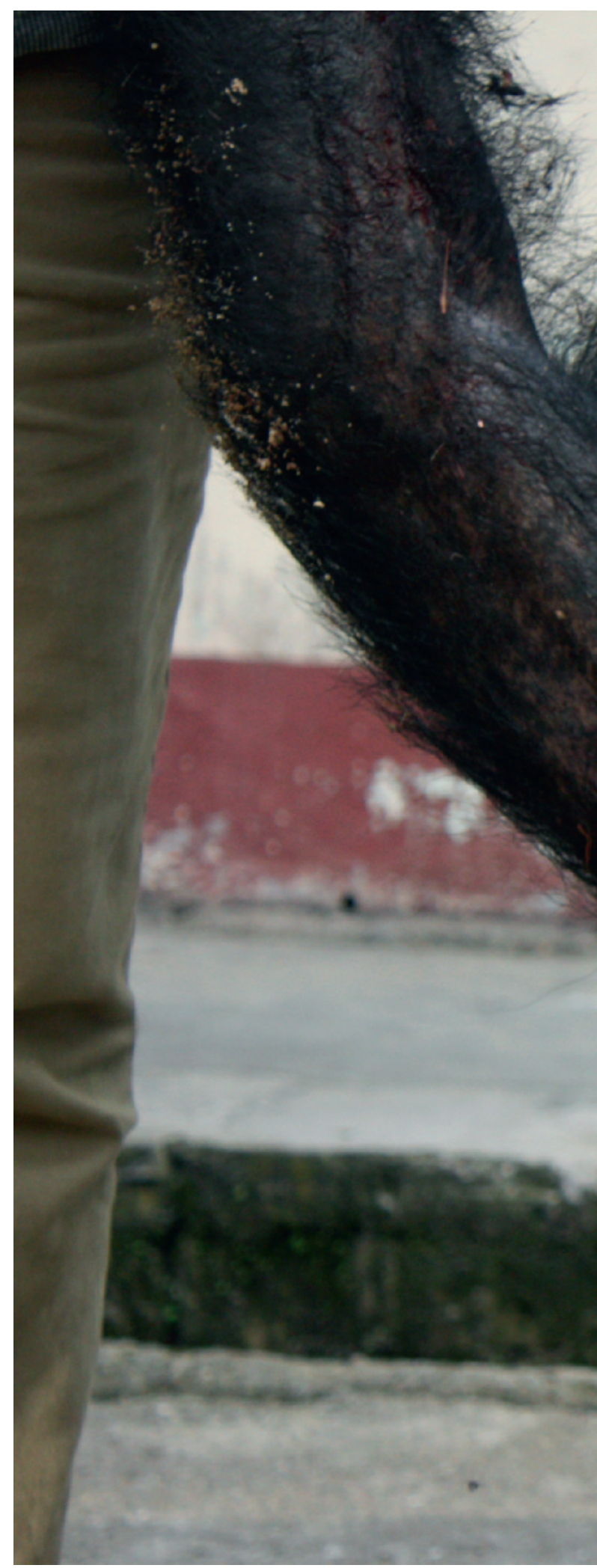


applications for trade in potentially wildcaught great apes:

Given the rarity of these taxa and the large numbers of captive-bred great apes currently held in zoos and other ex-situ collections, wild-caught great apes are not acceptable for trade among zoos, safari parks or other educational or scientific institutions except under extraordinary circumstances (CITES, 2018a, p. 23).

After discussing the report, the Standing Committee asked the Secretariat to review the provisions in Resolution 13.4 together with GRASP and IUCN, and to propose appropriate amendments for consideration at CoP18 in 2019 (CITES, 2018b, para. 52). Accordingly, the conference approved a resolution that largely repeats the conclusions of the report, including by noting that:

\footnotetext{
as all great ape species are well represented in zoos worldwide, there consequently may not be exceptional circumstances for which the removal of further great apes from the wild would be justified (CITES, 2019b, p. 1).
}

If fully implemented, the recommendations of the report and resolution would go some way to controlling the illegal trade in great apes and addressing pressures on habitats. Whether they will be effectively implemented in practice remains to be seen. Meanwhile, NGOs and others have suggested additional reforms to CITES procedures, including working with international zoological associations to establish a registry of accredited zoos and scientific institutions that might house great apes, especially those with breeding programs, in order to minimize abuse of the captive-bred exception. ${ }^{25} \mathrm{~A}$ more ambitious measure would be to require imported great apes to be registered and identified, for example through DNA profiles or inserted microchips.

\section{International Conservation Organizations and Agreements}

\section{Great Apes Survival Partnership}

An alliance of more than 100 conservation organizations, national governments, private companies, research institutions and UN agencies, GRASP was established in 2001 and is the only species-specific conservation program within the UN. Its six priorities are political advocacy, habitat protection, illegal trade, conflict-sensitive conservation, disease monitoring and the green economy. It works to promote awareness of these issues among other institutions and has been able to access funding and foster collaboration to deliver conservation projects (GRASP, n.d.-b). It has participated in technical missions with the CITES Secretariat, for example in April 2007 in Thailand and Cambodia, where the focus was on orangutans (CITES, 2007b). The publication Stolen Apes: The Illicit Trade in Chimpanzees, Gorillas, Bonobos and Orangutans-released in 2013 by GRASP, UNEP and GRID-Arendal-provides the first overview of the extent of the illicit global trade in great apes and includes recommendations for the mitigation of the impact of illegal trade on the remaining wild populations (Stiles et al., 2013).

In September 2016, GRASP followed up on one of the recommendations in Stolen Apes by launching the Apes Seizure Database. Developed together with UNEP-WCMC, the database consolidates data and reports of great apes seized around the world (GRASP, n.d.-a). Much of the illegal trade in these species does not meet the requirements for inclusion in other existing databases, such as the CITES Trade Database, which does not record transactions unless they cross national borders and which may thus lead some observers to underestimate the scale of the illegal trade (CITES, n.d.-e). ${ }^{26}$ The 
Apes Seizure Database allows providers to upload records directly from the field via smartphones; a panel of experts validates each record to ensure the quality of data (GRASP, n.d.-a). On its launch, the database contained information on seizures of more than 1,800 great apes in 23 nationsalmost half of which were not great ape range states-between 2005 and 2016 (UN Environment, 2016a).

Not unlike other organizations discussed in this chapter, GRASP suffers from a shortage of funding and capacity; in 2019, it was making do with just three staff members instead of the full five. Nevertheless, its research and advocacy efforts have been welcomed, and as the only intergovernmental organization dedicated to great apes, it clearly has the potential to play an important role in addressing the international illegal trade. ${ }^{27}$

\section{The Convention on Migratory Species and the Gorilla Agreement}

The Convention on the Conservation of Migratory Species of Wild Animals (CMS) entered into force in 1983. Operating under the aegis of UN Environment, the convention aims to conserve terrestrial, marine and avian migratory species throughout their range. CMS parties (130 as of November 2019) undertake to protect migratory species that are threatened with extinction (such as gorillas and chimpanzees), as well as species that need or would benefit significantly from international cooperation (including chimpanzees), by conserving or restoring the places where they live, mitigating obstacles to migration and controlling other factors that might endanger the animals (CMS, n.d.-a, n.d.-d, n.d.-e). The CMS effectively acts as a framework convention; more concrete commitments are entered into through specific global or regional treaties or less formal instruments such as memorandums of understanding. Efforts are under way to develop a new compliance regime to support parties in meeting their obligations (CMS, 2018).

Species-specific treaties under the CMS include the Agreement on the Conservation of Gorillas and Their Habitats, which entered into force in 2008. Intended to cover all ten gorilla range states, the Gorilla Agreement has been ratified by seven of them-the Central African Republic, the DRC, Gabon, Nigeria, the Republic of Congo, Rwanda and Uganda; the remaining three are Angola, Cameroon and Equatorial Guinea. The agreement aims to conserve and restore gorilla populations and promote the long-term survival of their forest habitat and dependent human populations, largely through the development of subspecies-specific action plans. Activities include monitoring gorilla populations and threats; strengthening law enforcement and anti-poaching measures; promoting alternatives to forest and gorilla overexploitation as sources of income, including ecotourism; building international collaboration between range states; and developing national strategies for gorilla conservation (CMS, n.d.-b, n.d.-c).

To date, the Gorilla Agreement has not been particularly successful in achieving any of these aims. An activity report presented at the CMS conference in 2014 summarizes limited progress with regional action plans and two small projects, one to support community-based forest conservation initiatives and the other to assist governments in increasing their wildlife law enforcement capacity and monitoring the illegal wildlife trade (CMS, 2014). The equivalent report presented at the CMS conference in 2017 features only a proposal for cooperating with GRASP and information about two additional small projects (CMS, 2017). GRASP's current shortages of staff and funding may affect its ability to achieve such cooperation. ${ }^{28}$ 
Photo: Enforcement action against the illegal trade can be effectively coordinated by INTERPOL and the WCO in particular, but they suffer from a shortage of resources and many competing priorities.

(c) Jabruson (www.jabruson. photoshelter.com)

\section{Biodiversity Convention}

The UN Convention on Biological Diversity (CBD), also known as the Biodiversity Convention, was signed in 1992 at the Rio Earth Summit and entered into force the following year. As of January 2020 it had 196 parties-almost universal participation, with the notable exception of the United States, which has signed the agreement but has not ratified it (CBD, n.d.-a, n.d.-b). The $\mathrm{CBD}$ has three main goals: the conservation of biodiversity, the sustainable use of its components, and the fair and equitable sharing of benefits arising from genetic resources. The convention is the first international agreement to recognize the conservation of biodiversity as "a common concern of humankind" and an integral part of the development process (Casetta, Marques da Silva and Vecchi, 2019). It covers all ecosystems, species and genetic resources; it also links traditional conservation efforts to the economic goal of using biological resources sustainably. CBD parties are required to draw up national biodiversity strategies and action plans and to ensure that they are mainstreamed into the planning and activities of all sectors whose activities can have an impact (positive or negative) on biodiversity (CBD, n.d.-a).

The requirement to draw up national strategies is legally binding, yet there are no real penalties for non-compliance or for any failure to implement meaningful policies or measures. Still, the CBD has helped to raise the profile of the issue, in part by initiating a series of studies on the economic impacts of the loss of biodiversity, which began with The Economics of Ecosystems and Biodiversity: An Interim Report (TEEB, 2008). The process of drawing up and implementing national strategies does appear to have assisted conservation efforts. It has also helped to mobilize financial support; from 1994 to the end of May 2016, the Global Environment Facility-a funding mechanism established

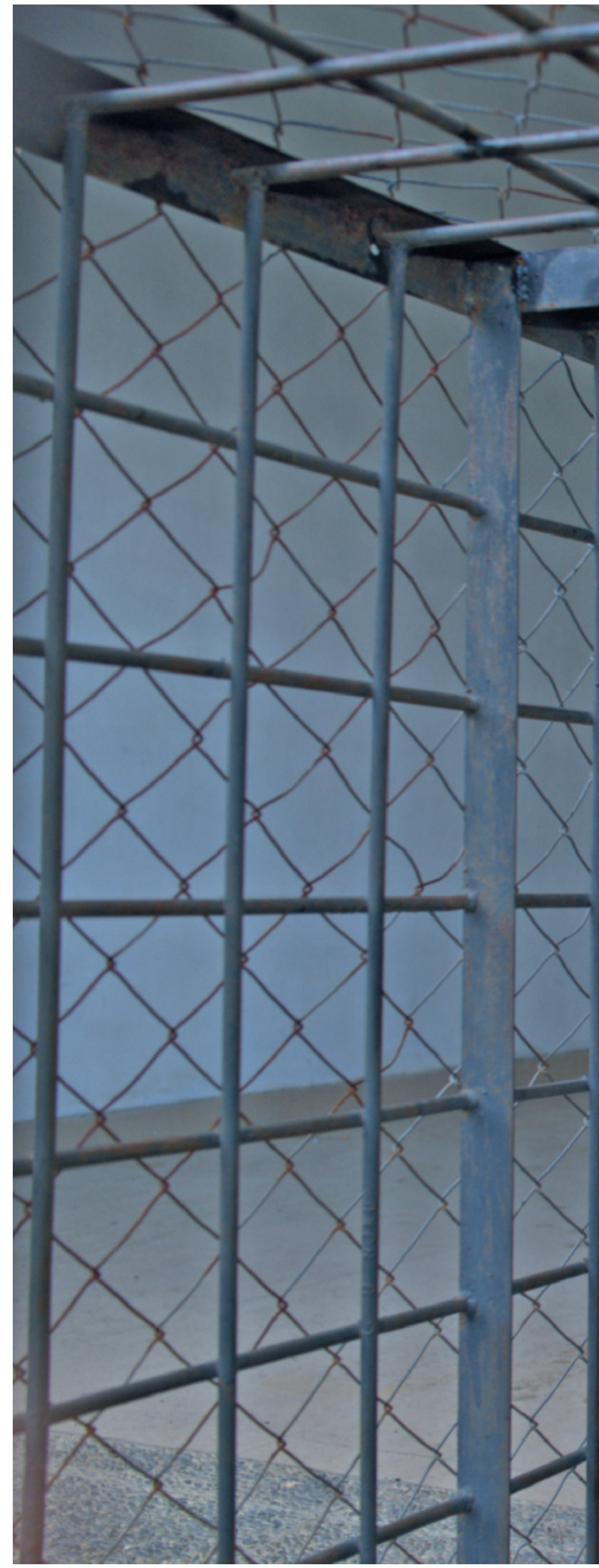




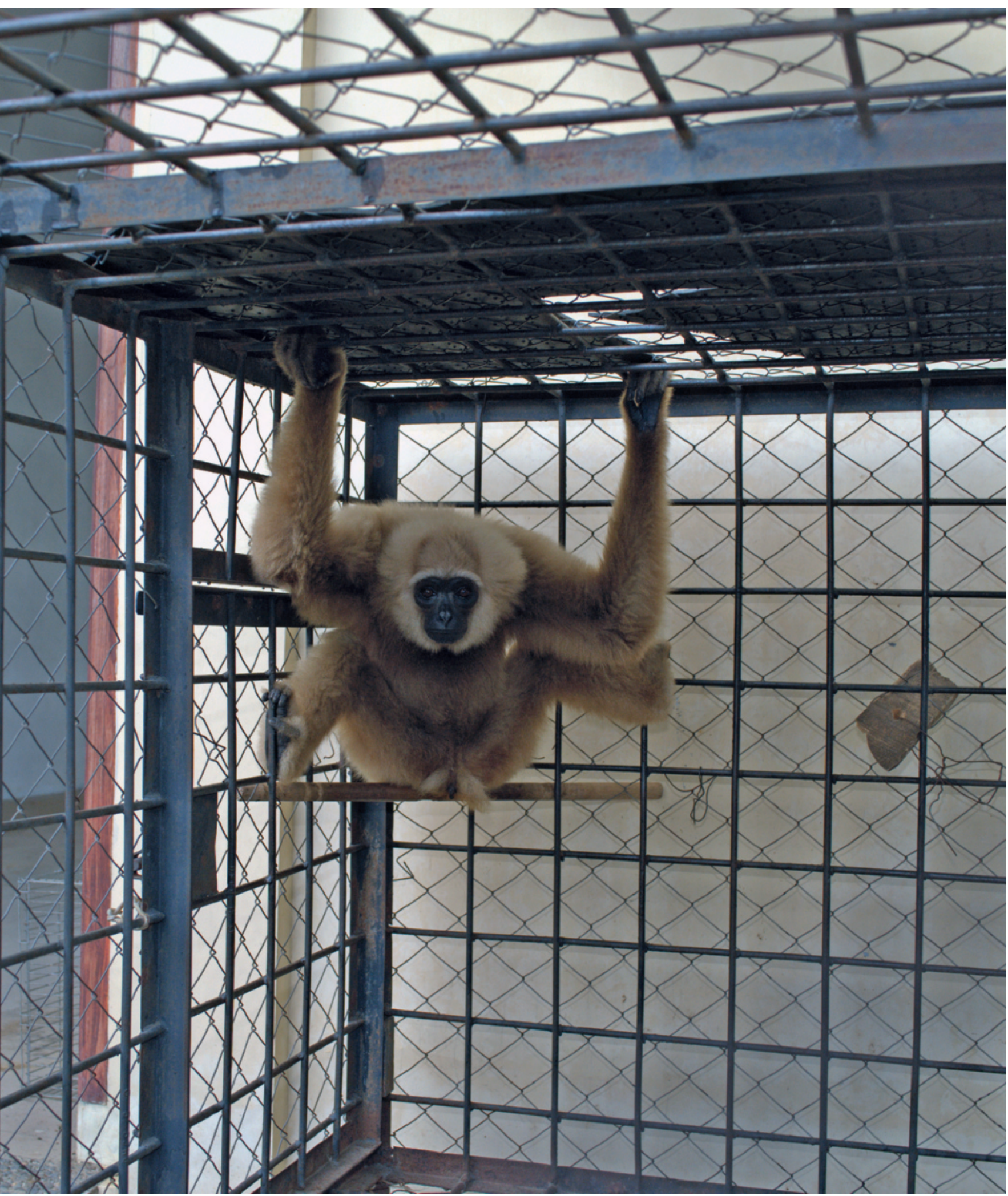


Wildlife crime is usually a low priority for customs agencies, particularly in developing countries, where revenue-generating activities often take priority over wildlife-related law enforcement operations. in 1992 to provide financial support to environmental initiatives, including several international conventions-provided support to about 1,300 national and regional biodiversity projects, with grants totaling US $\$ 3.4$ billion, generating co-financing of US $\$ 10.2$ billion (Ferreira de Souza Dias, 2016).

\section{International Law Enforcement Organizations and Agreements}

\section{World Customs Organization}

Established in 1952, the WCO aims to enhance the effectiveness and efficiency of customs administrations; as of January 2020, it had 183 members, covering 98 per cent of world trade. The WCO offers its members a forum for dialog and exchange of experiences between customs agencies, and technical assistance and training services for modernizing and building capacity in their national customs administrations (WCO, n.d.-g).

The WCO's Environment Programme focuses on combating environmental crime, including illegal trade in wildlife, timber, waste and chemicals. It tries to ensure that environmental issues are among the priorities of customs agencies, a difficult task given other calls on their resources and, often, a lack of awareness of the environmental impacts of illegal behavior (WCO, n.d.-b). The Environment Programme maintains WCO tools and instruments that are designed to facilitate enforcement, such as the Customs Enforcement Network application, which features a database of seizures and offenses as well as pictures of illicit goods (WCO, n.d.-c). In addition, it manages ENVIRONET, a realtime communication tool for information exchange among national authorities, international organizations and regional networks (WCO, n.d.-a). The WCO's annual Illicit Trade Report provides information on the Environment Programme's activities and an assessment of the extent of environmental crime worldwide (WCO, n.d.-e).

With assistance from donors, the WCO has run a series of programs to raise awareness of the illegal trade in wildlife and related corruption among customs officers, including international training workshops, seminars and joint enforcement operations. One such program was Project Gapin (Great Apes and Integrity), which, in 2010-11, not only aimed to raise awareness among customs officers of the illegal trade in wildlife and related corruption, but also provided assistance to a number of customs administrations in Africa (WCO, 2012, n.d.-d). The most recent initiative, Project INAMAfunded by CITES and the German, Swedish and US governments-aims to strengthen the enforcement capacity of customs administrations in sub-Saharan Africa. An initial assessment found that most countries in the region generally accorded a low priority to the illegal wildlife trade. Many had appropriate legal provisions in place but seldom used them. Half of the administrations did not have an intelligence unit in place, and none of them had intelligence officers dedicated specifically to wildlife issues. Under Project INAMA, training sessions and workshops have been held, technical assistance has been provided for evidence handling and seizures, and joint enforcement and intelligence operations and exchange of personnel have been encouraged (WCO, 2017).

The WCO's global intelligence and information gathering functions are supported by its 11 Regional Intelligence Liaison Offices (RILOs), some of which have been active in tackling environmental crime (WCO, n.d.-f). In 2013-14, for example, RILO Asia-Pacific and RILO Eastern and Southern Africa participated in three successive global enforcement operations (CITES, 2014). Operation Cobra III, launched in 2015, was the largest global operation ever to target transnational wildlife and forest crime, including offenses involving apes. 
The operation resulted in more than 300 arrests, more than 600 seizures of wildlife contraband, and tip-offs that led to the discovery of crime networks and other criminal activities (WWF, 2015).

The WCO and its RILOs are critical players in efforts to control the illegal trade in wildlife, but they are consistently hindered by a scarcity of resources and, in many national customs agencies, shortages of capacity, corruption and a lack of political will. Some of the data that national customs agencies report to the $\mathrm{WCO}$ are inaccurate, particularly on trade in environment-related items. As noted above, wildlife crime is usually a low priority for customs agencies, particularly in developing countries, where revenue-generating activities often take priority over wildlife-related law enforcement operations. ${ }^{29}$

\section{INTERPOL}

INTERPOL, the International Criminal Police Organization, was founded in 1923 and had 194 member countries in January 2020. It facilitates information exchange between national police authorities but does not investigate or prosecute cases (INTERPOL, n.d.-a). INTERPOL's Environmental Security Unit comprises four global enforcement teams, covering fisheries, forestry, pollution and wildlife. They provide national law enforcement agencies with tools and expertise, offer investigative support relating to international cases and targets, coordinate operations, and assist member countries in sharing information and studying environmental criminal networks. They are advised by an Environmental Compliance and Enforcement Committee, with four working groups that focus on the same four topics and bring together member countries to share experience and expertise and to facilitate international cooperation (INTERPOL, n.d.-b).
INTERPOL has coordinated a long series of international enforcement operations targeted at various forms of environmental crime. In 2016, for example, Operation Thunderbird, a global operation tackling the illegal trade in wildlife and timber, involved police, customs and border agencies, as well as environment, wildlife and forestry officials from 49 countries and territories and resulted in the identification of nearly 900 suspects and 1,300 seizures of illicit products worth an estimated US $\$ 5.1$ million (INTERPOL, 2017). None of INTERPOL's operations appears to have targeted great apes in particular, although several have resulted in seizures of wild meat.

INTERPOL encourages each of its member countries to establish a national environmental security task force to fight environmental crime. These multi-agency cooperatives involve the police, customs, environmental agencies, other specialized bodies, prosecutors, NGOs and intergovernmental partners in pursuit of a common goal, such as the reduction of pollution, the conservation of a particular species or the protection of forests, fish stocks or other natural resources (INTERPOL, 2012).

Like the WCO, INTERPOL has done good work on environmental crime and has a potentially valuable role to play in combating the illegal trade in great apes-by identifying and apprehending offenders and raising awareness of the issue. It is constrained by a lack of resources and many other competing priorities, however, and its effectiveness is undermined by wide variations in what is legal and what is illegal in member countries, the involvement of a huge range of law enforcement agencies (not just the police) and a general lack of knowledge of environmental crimes. ${ }^{30}$ It is most effective in coordinating national police forces that already strive to tackle wildlife crime; if a police force is not willing to do so-or is affected by corruption - there is little INTERPOL can do about it. 


\section{United Nations Office on Drugs and Crime}

UNODC was established in 1997 to assist UN member states in their struggle against illicit drugs, crime and terrorism. Unlike the WCO and INTERPOL, it is not an enforcement cooperation agency. Rather, it undertakes field-based technical cooperation and capacity-building; conducts research and analytical work, partly to increase knowledge and understanding, but also to expand the evidence base for policy and operational decisions; and works with states to develop national legislation, as well as to ratify and implement relevant international treaties, such as the UN Convention against Transnational Organized Crime (UNGA, 200o). It relies on voluntary contributions for the bulk of its budget and tends to suffer from chronic funding shortages and understaffing (UNODC, n.d.-a). ${ }^{31}$

Within UNODC, work on wildlife crime is organized through the four-year Global Programme for Combating Wildlife and Forest Crime. Activities are undertaken together with the wildlife law enforcement community to ensure that wildlife crime, illegal logging and related offenses are treated as serious transnational organized crimes. As part of this work, UNODC delivers technical assistance and capacity building, including by training and supporting rangers, police, customs, prosecutors, investigators and the judiciary. It also supports capacity building in intelligence gathering and strengthens interagency and cross-border cooperation (UNODC, n.d.-c).

In 2012, UNODC published the Wildlife and Forest Crime Analytic Toolkit. Designed mainly to assist government officials, the toolkit provides a comprehensive overview and discussion of measures related to legislation, enforcement, the judiciary and prosecution, drivers and prevention, and data and analysis. Its aim is to help wildlife, forestry, customs and other enforcement agencies to conduct a comprehensive analysis of possible means and measures to protect wildlife and forests, monitor their use and identify requirements for technical assistance; more broadly, it is designed to raise awareness, bring in donor support and stimulate international cooperation (UNODC, 2012). By September 2016, the toolkit had been successfully implemented in 7 countries and was at different stages of implementation in 12 others (CITES, 2016).

In 2016, UNODC published the World Wildlife Crime Report, an evaluation of the extent and nature of the problem at the global level. The report includes a quantitative market assessment based on information in the World Wildlife Seizure database, which was established to enable this analysis and contains data provided by CITES and the WCO. If maintained, the database will serve to provide key indicators and a potential early warning mechanism. The report also features a series of in-depth illicit trade case studies, including one on great apes (UNODC, 2016).

\section{United Nations Convention against Transnational Organized Crime}

UNTOC entered into force in 2003 and had 190 parties as of late 2019 (UNODC, n.d.-b). Parties commit themselves to taking a series of measures against transnational organized crime-defined as offenses committed by three or more persons acting togetherincluding by creating domestic criminal offenses; adopting frameworks for extradition, mutual legal assistance and law enforcement cooperation; and promoting training and technical assistance. In theory, UNTOC parties should be able to rely on one another in investigating, prosecuting and punishing crimes committed by organized criminal groups with some element of 
transnational involvement. The aim is to make it much more difficult for organized criminal groups to take advantage of gaps in national law, jurisdictional problems or a lack of accurate information about the full scope of their activities (UNGA, 2000; UNODC, n.d.-b).

According to observers, UNTOC has facilitated cooperation between enforcement agencies among different countries. ${ }^{32}$ Its impact is inevitably limited, however, as it depends on its parties' capacity and willingness to implement its suggested framework, and the convention has no non-compliance mechanism to ensure that its parties meet their obligations.

UNTOC refers to "illicit trafficking in endangered species of wild flora and fauna" but contains no specific provisions (UNGA, 2000, preamble). The UN General Assembly and individual states have called on governments to fulfill their commitments under the terms of the convention, in particular by defining wildlife crime as a "serious crime"meaning that it must carry a minimum penalty of at least four years' imprisonmentand also as a predicate offense for money laundering crimes (ECOSOC, 2013; London Conference on the Illegal Wildlife Trade, 2014). The evidence suggests that much of the illegal trade in great apes, particularly in high-value live specimens, is conducted by well-organized and sophisticated transnational criminal networks-groups that fall squarely within the remit of this convention (Stiles et al., 2013).

\section{International Consortium for Combating Wildlife Crime}

Founded in November 2010 by the CITES Secretariat, INTERPOL, UNODC, the WCO, and the World Bank, the International Consortium on Combating Wildlife Crime (ICCWC) is a collaborative association rather than an independent organization.
Its aim is to strengthen criminal justice systems and provide coordinated support at the national, regional and international levels to combat wildlife and forest crime. A number of European countries and the United States have provided funding (CITES, 2019c, n.d.-h).

ICCWC worked together with UNODC in publishing the above-mentioned Wildlife and Forest Crime Analytic Toolkit in 2012 and the World Wildlife Crime Report in 2016 (UNODC, 2012, 2016). ICCWC has also established an indicator framework, which allows national law enforcement authorities to assess their own capacity to fight wildlife and forest crime; deployed wildlife incident support teams to assist countries that have been affected by significant poaching or that have made large-scale seizures; provided specialized training for wildlife law enforcement officers; coordinated a number of enforcement operations, such as Cobra III; developed practical tools and guidelines for forensic methods and procedures for ivory and timber sampling and analysis; and launched an anti-money laundering training course (CITES, 2015c).

To date, ICCWC has been successful in generating a high profile and attracting significant levels of funding. The involvement of the World Bank has been helpful in drawing attention to the connections between money laundering and wildlife crime. The consortium has been criticized for lacking flexibility in responding to new situationstied as it is to its partners' agendas and institutional structures-but in general it is credited with having a positive impact, albeit not specifically on apes. ${ }^{33}$

\section{Other Collaborative Initiatives}

As noted above, effective action against wildlife crime benefits substantially from collaboration among several different agencies, including the police, prosecutors, customs, 


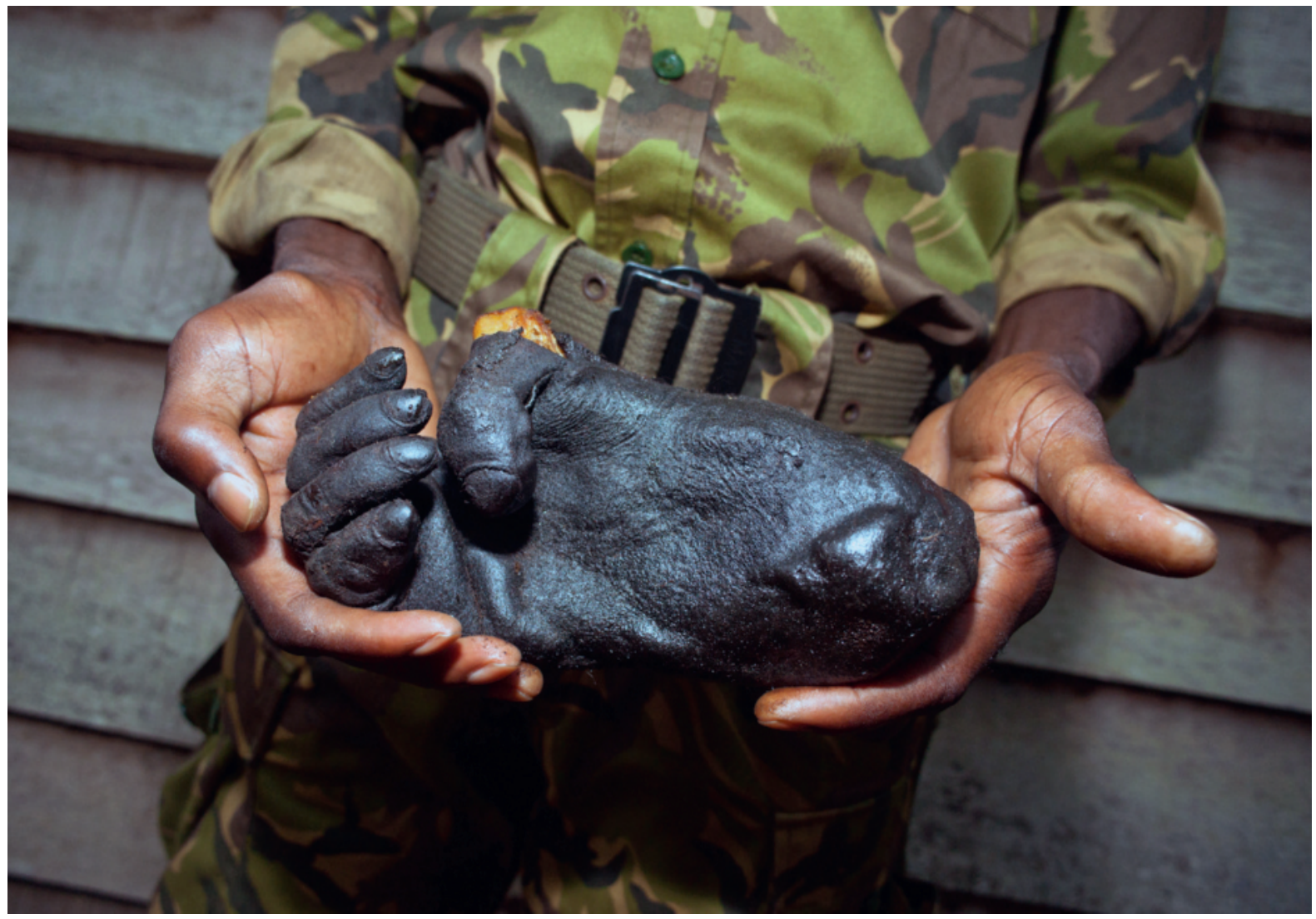

Photo: Effective action against the international illegal trade in apes whether as live specimens, body parts or wild meatrequires both an adequate legal framework and the resources, capacity and political will to use it. Ranger holding a smoked gorilla hand. () Jabruson (www. jabruson.photoshelter.com) wildlife and forest rangers, and environment departments. This is true at the international level as much as it is at the national level, and various initiatives-including ICCWChave been undertaken to foster such collaboration. Both the WCO and INTERPOL have formal memorandums of understanding with the secretariats of relevant multilateral environmental agreements (MEAs), including CITES, and also with a number of NGOs working on the issues (CITES and ICPOINTERPOL, 1998; CITES and WCO, 1996).

Another effort is the Green Customs Initiative, which was established in 2004 and involves INTERPOL, UN Environment, the WCO and the secretariats of several MEAs, including CITES (Green Customs, n.d.). The initiative has helped to facilitate information exchange, joint technical meetings and cooperation between environment and customs officials at the national level. It has also participated in training and awareness raising exercises, although its partners are largely responsible for organizing the workshops and providing training materials, since the initiative has very little of its own capacity (Green Customs, n.d.). ${ }^{34}$ Some of the MEA secretariats have benefited from their newly established interaction with the customs community, but observers note that activities are limited and that momentum has been lost over the years. ${ }^{35}$

A number of regional wildlife enforcement networks have been established to offer a platform for regional collaboration among national environment and law enforcement agencies, CITES authorities and others. Such networks also enable countries to monitor wildlife crime, share information, develop capacity for enforce- 
ment and investigations, and learn from each other's best practices (CITES, 2019d; ICCWC, 2013, 2016). One of the best-funded networks, thanks largely to support from the United States, was the Association of Southeast Asian Nations (ASEAN) Wildlife Enforcement Network. Each of the ten ASEAN member countries was charged with setting up an interagency task force comprising police, customs and environment officials; focal points from national task forces then shared intelligence with each other throughout the region. By 2015 eight ASEAN countries had each formed a national task force, training was being offered in anti-poaching operations and wildlife crime investigations, and arrests and seizures of illegal wildlife were increasing (Freeland Foundation/ASEAN-WEN, 2016; USAID, 2015). Very few of the arrests ever led to prosecutions, however, perhaps because of bribery and corruption. ${ }^{36}$ In 2017 the network was merged into the ASEAN Experts Group on CITES to form the ASEAN Working Group on CITES and Wildlife Enforcement (AWG CITES and WE, n.d.).

Other regional wildlife enforcement networks exist, although some are not particularly active. The Lusaka Agreement Task Force, based on a formal agreement, has powers to investigate violations of wildlife laws, undertake intelligence gathering, conduct joint investigations and enforcement actions within and across its member countries' borders, and provide training to national agencies (UN Environment, 2016b). In 2013, 2016 and 2019, the CITES Secretariat and ICCWC convened meetings of all the networks and other interested organizations, alongside the CITES CoP meetings, to promote cooperation and exchange of information (CITES, 2019d; ICCWC, 2013, 2016).

In theory, regional wildlife enforcement networks have the potential to enhance cooperation and effectiveness; in practice, however, they can be time-consuming and bureaucratic to establish, and they always require donor funding. Given that resources are limited, it may prove more valuable to target support on establishing national collaborative networks and mechanisms for direct bilateral cooperation between affected countries.

\section{International Frameworks: Conclusions}

Effective action against the international illegal trade in apes-whether as live specimens, body parts or wild meat-requires both an adequate legal framework and the resources, capacity and political will to use it.

In principle, CITES provides many elements of an adequate legal framework at the international level. It currently suffers from a number of weaknesses that could be corrected, for example if CITES parties fully implement the recommendations set out in the 2018 report to the CITES Standing Committee and included in the 2019 resolution (CITES, 2018a, 2019b). In particular, the rejection of any applications for trade in potentially wild-caught apes, except in exceptional circumstances, would help to end the current abuse of the system by safaris, amusement parks and so-called zoos.

A bigger problem than the design of CITES is the lack of capacity, resources and political will in many of its parties, particularly in the ape range states and in countries that see imports of apes for commercial purposes. Too many management authorities fail to apply the correct procedures for issuing and checking the validity of export and import permits; corruption and fraud are persistent problems.

Once apes are illegally traded, either through fraud or circumvention of the CITES permit system, several of the other organizations reviewed in this chapter come into play. The WCO and its RILOs and INTERPOL 


66 In the context
of the illegal
wildlife trade,
apes have not
managed to
achieve the
same profile and
levels of public
awareness as
other species,
such as
elephants. 99

are particularly important in taking enforcement action against illegal trade; GRASP, ICCWC and UNODC all have supportive roles to play in research, data and intelligence gathering, awareness raising, training and capacity building.

All of these organizations, however, suffer from similar problems in addressing the trade in apes, including a shortage of resources, as most of them are dependent on external funding rather than a core budget to carry out activities on wildlife crime. They must also deal with many competing priorities, in terms of other species, other areas of environmental crime and other areas of crime in general. Dedicated support from donors, whether public or private, will always be needed to underpin effective action.

In the context of the illegal wildlife trade, apes have not managed to achieve the same profile and levels of public awareness as other species, such as elephants. This is the case not only in Western countries but in many range states, where it is not unusual for chimpanzees or orangutans to be kept as pets, or for trade in body parts or wild meat to be regarded as acceptable. Complicating matters is the thriving demand for live apes for commercial or private entertainment purposes in many countries (Head, 2017; see Chapter 4). Awareness raising activities, research and campaigning are therefore just as important as law enforcement activities in helping to reduce demand. While some of the organizations reviewed in this chapter, such as GRASP and UNODC, carry out these roles, many more bodies-NGOs, research institutes and universities-do so as well, and they need to be supported.

\section{Acknowledgments}

Principal authors: The National Legal Environment: Jim Wingard, Maria Pascual, and Maribel Rodrigue ${ }^{37}$ International Frameworks: Duncan Brack ${ }^{38}$

\section{Endnotes}

1 On the Legal Atlas website, sign up for free and select the topic "Wildlife Trade" on the top menu search bar, then the "Legal Framework" database and then any of the 17 studied jurisdictions, either by clicking on the map or by choosing from the country selector. The map indicates which other countries have also been researched (Legal Atlas, n.d.).

2 Great ape range states comprise two countries in Asia-Indonesia and Malaysia-and 21 countries in Africa-Angola, Burundi, Cameroon, Central African Republic, the Democratic Republic of Congo (DRC), Equatorial Guinea, Gabon, Ghana, Guinea, Guinea Bissau, Ivory Coast, Liberia, Mali, Nigeria, the Republic of Congo, Rwanda, Senegal, Sierra Leone, South Sudan, Tanzania and Uganda (GRASP, n.d.-c). The 12 italicized states are reviewed in this legal assessment.

3 Gibbon range states comprise 11 Asian countries: Bangladesh, Brunei, Cambodia, China, India, Indonesia, Lao People's Democratic Republic (PDR), Malaysia, Myanmar, Thailand and Viet Nam (https://www.iucnredlist.org). The seven italicized states form part of this legal assessment.

4 As noted in the introduction to this chapter, this section summarizes the findings of Rodriguez et al. (2019). Supplementary sources are cited throughout the section.

5 The Legal Atlas Research Protocol for Wildlife Trade, an internal guide for legal analysts, outlines 43 types of law and their potential relationship to the governance of wildlife trade activities and transactions.

6 Laws differentiate between species only as much as deemed necessary by the drafters. Reference to a species includes all subspecies unless otherwise indicated.

7 Laws differentiate between species only as much as deemed necessary by the drafters. Reference to a species includes all subspecies unless otherwise indicated. Eastern gorilla therefore includes both Grauer's gorilla and the mountain gorilla.

8 Laws differentiate between species only as much as deemed necessary by the drafters. Reference to a species includes all sub-species unless otherwise indicated. Western gorilla therefore includes both the Cross River gorilla and the western lowland gorilla.

9 Laws differentiate between species only as much as deemed necessary by the drafters. Reference to a species includes all subspecies unless otherwise indicated. 

in current taxonomy (see the Apes Overview). This change has not been reflected in the laws in China. It may only cover the eastern hoolock, as the laws pre-date the identification of the Gaoligong hoolock and the western hoolock is not native to China. in current taxonomy (see the Apes Overview). This change has not been reflected in the laws in Myanmar. It may only cover the eastern hoolock, as the laws pre-date the identification of the Gaoligong hoolock and the western hoolock is not native to Myanmar. the western lowland gorilla (Gorilla g. gorilla) and the Cross River gorilla (Gorilla g. diehli) - the law refers only to the former.

13 See the resolutions arising from meetings of the Conference of the Parties held between 1979 and 2016. Resolutions can be used to amend Appendices I, II or III, which are "lists of species afforded different levels or types of protection from overexploitation" (CITES, n.d.-g).

The finding that all 17 jurisdictions regulate capture and sale is based on the assumption that the term "trade" (as used in 7 of the jurisdictions) is broad and has applicability not only to financial transactions involving captive animals, such as the sale of a gibbon, but also to the capture of those animals.

Rica, for example, provides for three different penalty segments in its main customs law, the 1995 Ley General de Aduanas, for the crime of smuggling. Under that law, penalties for smuggling any good (including wildlife) are governed by Article 211 for individual offenders, by Article 225(b) for legal entities or corporations and by Article 225(a) for government officials (Ley General de Aduanas, 1995).

This review covers 110 jurisdictions and discusses the degree to which the illegal wildlife trade is a predicate for money laundering offenses (Wingard and Pascual, 2019).

17 Hunting protected species (Class A and Class B) in Cameroon carries a fine of CFA 50,000-200,000 (US\$80-350) for individuals, as per the Forestry, Wildlife and Fisheries Law (National Assembly of Cameroon, 1994, arts. 78, 101, 146, 155, 162).

Money laundering of proceeds from wildlife trade crimes that qualify as environmental crimes carries a minimum fine of CFA 10 million (US $\$ 17,000$ ) as per the anti-money laundering and terrorism financing regulation of the Economic and Monetary Community of Central Africa, which Cameroon and other Community members have adopted. The same regulation doubles the fine if organized criminal networks play a role in the money laundering, bringing the minimum financial penalty to CFA 20 million (US\$35,00o) (CEMAC, 2016, arts. 1(19), 8, 114, 116(3)).

19 Administrative penalties comprise a variety of civil sanctions, including financial penalties. In this review, the concept was limited to a subset of penalties applicable to government officials and to license or permit holders.

20 Community service is an alternative form of penalty that supports the goal of rehabilitation without incarceration. It is used in Canada, Germany, the United Kingdom and the United States, among other jurisdictions.

21 Annual reports are publicly accessible through the CITES Trade Database, enabling NGOS and independent researchers to carry out these kinds of check on an ad hoc basis (CITES, n.d.-n).

$22 \mathrm{CoP} 16$ amended Resolution 13.4 in 2013 (CITES, 2013b).

23 Author interviews with wildlife trade and crime experts from UN agencies, academia and NGOs, December 2017-February 2018.

24 Author interviews with wildlife trade and crime experts from UN agencies, academia and NGOs, December 2017-February 2018.

25 Author interviews with wildlife trade and crime experts from UN agencies, academia and NGOs, December 2017-February 2018.

26 Author interviews with wildlife trade and crime experts from UN agencies, academia and NGOs, December 2017-February 2018.

27 Author interviews with wildlife trade and crime experts from UN agencies, academia and NGOs, December 2017-February 2018.

28 Author interviews with wildlife trade and crime experts from UN agencies, academia and NGOs, December 2017-February 2018.

29 Author interviews with wildlife trade and crime experts from UN agencies, academia and NGOs, December 2017-February 2018.

30 Author interviews with wildlife trade and crime experts from UN agencies, academia and NGOs, December 2017-February 2018.

31 Author interviews with wildlife trade and crime experts from UN agencies, academia and NGOs, December 2017-February 2018. 
32 Author interviews with wildlife trade and crime experts from UN agencies, academia and NGOs, December 2017-February 2018.

33 Author interviews with wildlife trade and crime experts from UN agencies, academia and NGOs, December 2017-February 2018.

34 Author interviews with wildlife trade and crime experts from UN agencies, academia and NGOs, December 2017-February 2018.

35 Author interviews with wildlife trade and crime experts from UN agencies, academia and NGOs, December 2017-February 2018.

36 Author interviews with wildlife trade and crime experts from UN agencies, academia and NGOs, December 2017-February 2018.

37 At the time of writing, all were at Legal Atlas (www.legal-atlas.net).

38 Independent researcher (www.dbrack.org.uk). 